\title{
A Subtype of Olfactory Bulb Interneurons Is Required for Odor Detection and Discrimination Behaviors
}

\author{
Hiroo Takahashi, ${ }^{1 \star}$ Yoichi Ogawa, ${ }^{2 *}$ Q $S e i-i c h i$ Yoshihara, ${ }^{1}$ Ryo Asahina, ${ }^{1}$ Masahito Kinoshita, ${ }^{1}$ Tatsuro Kitano, ${ }^{1}$ \\ Michiko Kitsuki, ${ }^{1}$ Kana Tatsumi, ${ }^{1}$ Mamiko Okuda, ${ }^{1}$ @Kouko Tatsumi, ${ }^{3}{ }^{\circledR}$ Akio Wanaka, ${ }^{3}$ @Hirokazu Hirai, ${ }^{4}$ \\ Peter L. Stern, ${ }^{5}$ and ${ }^{\circ}$ Akio Tsuboi ${ }^{1}$ \\ ${ }^{1}$ Laboratory for Molecular Biology of Neural System, Advanced Medical Research Center, ${ }^{2}$ Department of Physiology I, and ${ }^{3}$ Department of Anatomy II, \\ Nara Medical University School of Medicine, Kashihara, Nara 634-8521, Japan, ${ }^{4}$ Department of Neurophysiology, Gunma University Graduate School of \\ Medicine, Gunma 371-8511, Japan, and 5Institute of Cancer Sciences, Paterson Building, University of Manchester, Manchester M20 4BX, United Kingdom
}

Neural circuits that undergo reorganization by newborn interneurons in the olfactory bulb $(\mathrm{OB})$ are necessary for odor detection and discrimination, olfactory memory, and innate olfactory responses, including predator avoidance and sexual behaviors. The $\mathrm{OB}$ possesses many interneurons, including various types of granule cells $(\mathrm{GCs})$; however, the contribution that each type of interneuron makes to olfactory behavioral control remains unknown. Here, we investigated the in vivo functional role of oncofetal trophoblast glycoprotein 5T4, a regulator for dendritic arborization of 5T4-expressing GCs (5T4 GCs), the level of which is reduced in the OB of 5T4 knock-out (KO) mice. Electrophysiological recordings with acute OB slices indicated that external tufted cells (ETCs) can be divided into two types, bursting and nonbursting. Optogenetic stimulation of 5T4 GCs revealed their connection to both bursting and nonbursting ETCs, as well as to mitral cells (MCs). Interestingly, nonbursting ETCs received fewer inhibitory inputs from GCs in 5T4 KO mice than from those in wild-type (WT) mice, whereas bursting ETCs and MCs received similar inputs in both mice. Furthermore, 5T4 GCs received significantly fewer excitatory inputs in 5T4 KO mice. Remarkably, in olfactory behavior tests, 5T4 KO mice had higher odor detection thresholds than the WT, as well as defects in odor discrimination learning. Therefore, the loss of 5T4 attenuates inhibitory inputs from 5T4 GCs to nonbursting ETCs and excitatory inputs to 5T4 GCs, contributing to disturbances in olfactory behavior. Our novel findings suggest that, among the various types of $\mathrm{OB}$ interneurons, the $5 \mathrm{~T} 4 \mathrm{GC}$ subtype is required for odor detection and discrimination behaviors.

Key words: dendritic arborization; odor detection; odor discrimination; olfactory bulb interneuron; optogenetics; transmembrane protein

Significance Statement

Neuronal circuits in the brain include glutamatergic principal neurons and GABAergic interneurons. Although the latter is a minority cell type, they are vital for normal brain function because they regulate the activity of principal neurons. If interneuron function is impaired, brain function may be damaged, leading to behavior disorder. The olfactory bulb $(\mathrm{OB})$ possesses various types of interneurons, including granule cells (GCs); however, the contribution that each type of interneuron makes to the control of olfactory behavior remains unknown. Here, we analyzed electrophysiologically and behaviorally the function of oncofetal trophoblast glycoprotein 5T4, a regulator for dendritic branching in $\mathrm{OB}$ GCs. We found that, among the various types of $\mathrm{OB}$ interneuron, the 5T4 GC subtype is required for odor detection and odor discrimination behaviors.

\section{Introduction}

Sensory experience plays a crucial role in the development and plastic modification of neural circuits in vertebrates (Sanes and

Received July 20, 2015; revised June 29, 2016; accepted July 4, 2016.

Author contributions:H.T., Y.O., and A.T. designed the research;H.T., Y.O.,S.Y., R.A., M. Kinoshita, T.K., M. Kitsuki, Kana Tatsumi, and M.O. performed the research; Kouko Tatsumi, A.W., H.H., and P.L.S. contributed reagents/ animals/analytic tools; H.T., Y.O., S.Y., and A.T. analyzed the data; H.T., Y.O., S.Y., and A.T. wrote the paper.

This work was supported by Grants-in-Aid for Scientific Research on (B) (A.T.), (C) (H.T. and S.Y.), and Innovative Areas (Adaptive Circuit Shift; A.T.), and for Challenging Exploratory Research (A.T.) from the Ministry of Education, Culture, Sports, Science and Technology (MEXT), Japan. A.T. was supported by grants from the Smoking Research
Lichtman, 2001; Nithianantharajah and Hannan, 2006; Lepousez et al., 2013). Specific odorants activate olfactory sensory neurons that express corresponding odorant receptors (Mori and Sakano,
Foundation, Japanese Applied Enzymology Foundation, Senshin Medical Research Foundation, and Ono Medical Research Foundation, and a Nara Medical University Grant-in-Aid for Collaborative Research Projects in Japan. H.T. and S.Y. were supported by grants from the Takeda Science Foundation and the Astellas Foundation for Research on Metabolic Disorders, Japan. H.T. was supported by the Salt Science Research Foundation (Grant 14C3), the Mishima Kaiun Memorial Foundation, and the Banyu Life Science International Foundation in Japan. S.Y. was supported by a grant from Terumo Foundation for Life Sciences and Arts. We thank Dr. Yasuhiko Saito for electrophysiological analysis and the animal facility staff of Nara Medical University for their expert assistance. 
2011). Olfactory sensory neurons project their axons to specific glomeruli in the olfactory bulb $(\mathrm{OB})$ and can subsequently activate a specific neural circuit locally, facilitating dendritic development in interneurons via mitral cells (MCs) and tufted cells (TCs) within the OB (Mori and Sakano, 2011; Lepousez et al., 2013). OB interneurons are generated in the subventricular zone (SVZ) of the lateral ventricle (LV), migrate along the rostral migratory stream, and differentiate into GABA-releasing inhibitory interneurons such as granule cells (GCs) and periglomerular cells (PGCs) in the OB throughout life (Lledo et al., 2008; Whitman and Greer, 2009; Adam and Mizrahi, 2010; Kaneko et al., 2010; Sakamoto et al., 2011). Interestingly, adult-born OB interneurons are required for odor detection, odor discrimination, olfactory memory, and innate olfactory responses, including predator avoidance and sexual behaviors (Breton-Provencher et al., 2009; Sakamoto et al., 2011, 2014; Alonso et al., 2012; Nunes et al., 2015). Odor-evoked activity affects the survival and integration of newborn $\mathrm{OB}$ interneurons in preexisting neural circuits (Rochefort et al., 2002; Yamaguchi and Mori, 2005; Lin et al., 2010). Moreover, olfactory sensory deprivation and odor-rich environments can promote the suppression and acceleration, respectively, of dendritic morphogenesis and spinogenesis of newborn OB interneurons (Saghatelyan et al., 2005; Livneh et al., 2009). Importantly, among various OB interneurons, GCs are the largest population and are subdivided into several subtypes based on their morphology and cell lineage (Orona et al., 1983; Shepherd et al., 2004; Merkle et al., 2014); however, the functional specificity that distinguishes each GC subtype remains poorly understood because of the difficulty in genetically manipulating each OB interneuron subtype alone.

Oncofetal trophoblast glycoprotein 5T4 was first identified in cancer cells (Hole and Stern, 1990). It is expressed at a low level in most normal tissues (Southall et al., 1990), except for the brain and ovary (King et al., 1999; Barrow et al., 2005). We recently identified the $5 T 4$ gene, which is expressed in a unique subtype of OB GCs, termed 5T4 GCs, located in the MC and superficial GC layers (Imamura et al., 2006; Yoshihara et al., 2012). 5T4 regulates the dendritic arborization of 5T4 GCs in a sensory-input-dependent manner (Yoshihara et al., 2012). In this study, we performed electrophysiological and behavioral analyses to understand the in vivo functional role of 5T4 protein in OB GCs. Electrophysiological recordings with acute OB slices indicated that external tufted cells (ETCs) can be divided into two types, bursting and nonbursting. Photostimulation of channelrhodopsin2 (ChR2)-expressing 5T4 GCs revealed their connection to both bursting and nonbursting ETCs, as well as to MCs. Interestingly, in 5 T4 knock-out (KO) mice, nonbursting ETCs showed smaller GABAergic inputs evoked by activation of their interacting GCs than in wild-type (WT) mice, whereas bursting ETCs and MCs received similar GABAergic inputs in 5T4 KO and WT mice. Notably, 5T4 KO mice, which had less 5T4 GC dendritic branching than WT mice, showed remarkably higher odor detection thresholds and defects in odor discrimination learning; nevertheless, they were able to detect an odor of interest in the absence of a background odor in both food finding and odor

The authors declare no competing financial interests.

*H.T. and Y.O. contributed equally to this work.

Correspondence should be addressed to Akio Tsuboi, Laboratory for Molecular Biology of Neural System, Advanced Medical Research Center, Nara Medical University, 840 Shijo-cho, Kashihara, Nara 634-8521, Japan. E-mail: atsuboi@naramed-u.ac.jp.

DOI:10.1523/JNEUROSCI.2783-15.2016

Copyright $\odot 2016$ the authors $\quad 0270-6474 / 16 / 368211-18 \$ 15.00 / 0$ discrimination learning tests. These results suggest that 5T4 $\mathrm{GC}$ is required for odor detection and odor discrimination behaviors.

\section{Materials and Methods}

Animals. A 5T4 KO mouse line was generated as described previously (Southgate et al., 2010; RRID:MGI:4459403). The cells were then used to produce chimeric mice and germline progeny; $5 T 4$ heterozygous mice $\left(5 \mathrm{~T}^{+/-}\right.$) were backcrossed to the C57BL/6 background. The $5 T 4$ homozygous null $\left(5 \mathrm{~T}^{-{ }^{-}}{ }^{-}\right.$) C57BL/6 animals are viable, but adult animals show some structural disorganization within the brain and exhibit a high frequency of hydrocephalus (Southgate et al., 2010). We used 5T4 ${ }^{-i-}$ male mice for all behavioral tests. Ai32 [Rosa26-ChR2-enhanced yellow fluorescent protein (EYFP)] reporter mice, conditionally producing an improved ChR2-EYFP fusion protein, have been described previously (Madisen et al., 2012; RRID:IMSR_JAX:012569).

Generation and injection of lentiviral vectors. Lentiviral vectors were provided kindly by Dr. Nienhuis (St. Jude Children's Research Hospital). Recombinant lentiviral vectors, harboring the $5 T 4$ promoter $(6 \mathrm{~kb})$-driven gapEYFP (5T4p-gapEYFP) and 5T4p-Cre constructs, and the cytomegalovirus $(C M V)$ promoter-driven gapEYFP (CMVp-gapEYFP) construct, were prepared as described previously (Torashima et al., 2006; Yoshihara et al., 2012). For $5 T 4$ knock-down (KD) experiments, three sets of short hairpin RNAs (shRNAs) targeting the 5T4 gene were prepared as described previously (Yoshihara et al., 2012). As a negative control in the KD experiments, the following three sets of scramble shRNAs were used: scramble shl, GGTA CATATAGCATCTAGATTCAAGAGATCTAGATGCTATATGTACC CTTTTTT; scramble sh2, GATCTGATTCTATGTGTCTTATTCAAGAGA TAAGACACATAGAATCAGATCTTTTT; and scramble sh3, GCTAC TATGCTACTAGTATTATTCAAGAGATAATACTAGTAGCATAGTA GCTTTTT. Neonatal mice at postnatal day 1 (P1) to P3 were anesthetized with ice and then $0.5 \mu \mathrm{l}$ of lentiviral vector was injected into the LV using an Injection Pump KDS 310 (KD Scientific). The lentivirus titers were adjusted to $2.0 \times 10^{8} \mathrm{TU} / \mathrm{ml}$.

Immunohistochemistry (IHC). IHC of mouse $\mathrm{OB}$ sections was performed as described previously (Yoshihara et al., 2005, 2012, 2014) using the following antibodies: rabbit anti-GFP antibody (1:1000; Thermo Fisher Scientific catalog \#A-11122, RRID:AB_2576216); sheep anti-5T4 antibody (1:1000; R\&D Systems catalog \#AF5049, RRID:AB_2272148); chicken anti-LacZ antibody (1:1000; Abcam catalog \#ab9361, RRID: AB_307210); rabbit anti-cholecystokinin (CCK8) antibody (1:1000; Sigma-Aldrich catalog \#C2581, RRID:AB_258806); mouse anti-PGP9.5 antibody (1:100; Abcam catalog \#ab8189, RRID:AB_306343); and rat anti-BrdU antibody (1:1000; Abcam catalog \#ab6326, RRID: AB_305426). DyLight 488-, DyLight 549-, and DyLight 649-conjugated secondary antibodies were purchased from Jackson ImmunoResearch. DAPI nuclear counterstaining was performed on all OB sections. Images were acquired using an IX71 microscope (Olympus) equipped with a CCD camera DP30BW (Olympus) or a confocal laser microscope (FV1000-D; Olympus). Stacked images in the $X-Y$ plane from individual thin-sectioned slices were superimposed using Adobe Photoshop to reveal the entire morphology of the cells.

In situ hybridization (ISH). Single and double ISH procedures were performed as described previously (Tsuboi et al., 1999; Serizawa et al., 2006; Yoshihara et al., 2012). The coding regions of 5T4 (434-1714 nt; GenBank no. NM_001164792.1) and cFos (301-1500 nt; GenBank no. NM_010234.2) were used as templates for digoxigenin- or fluoresceinlabeled RNA probes (Roche Diagnostics).

BrdU labeling and detection. To determine the number of newly generated cells, a marker of cell proliferation, BrdU $(10 \mathrm{mg} / \mathrm{ml}$; Nacalai Tesque) was administered intraperitoneally ( $100 \mu \mathrm{g} / \mathrm{g}$ of body weight dissolved in PBS). After $14 \mathrm{~d}$, the BrdU-labeled cells were detected as described previously (Ishii et al., 2004).

Golgi-Cox staining. The Golgi-Cox method was used to stain neurons as described previously (Ranjan et al., 2010). The following criteria were used for identification of each cell type. ETCs were identified based on (1) their location between the glomerular layer (GL) and external plexiform layer (EPL), (2) their larger cell body compared with that of interneurons 
(>20 $\mu \mathrm{m}$ ), and (3) the elongation of their axons to the deeper EPL (Shepherd et al., 2004). MCs were identified based on (1) their location in the MCL, (2) their larger cell body compared with that of the GCs $(>20 \mu \mathrm{m})$, and (3) the elongation of their axons to the internal plexiform layer.

Acute slice preparation. Mice at 4-6 weeks of age (P28-P42) were anesthetized with isoflurane and decapitated. The brain was removed and rapidly immersed in ice-cold solution containing the following (in mM): sucrose 230, $\mathrm{KCl} 2.5, \mathrm{NaHCO}_{3} 25, \mathrm{NaH}_{2} \mathrm{PO}_{4} 1.25, \mathrm{CaCl}_{2} 0.5$, $\mathrm{MgSO}_{4} 10$, and D-glucose 10 bubbled with $95 \% \mathrm{O}_{2} / 5 \% \mathrm{CO}_{2}$. Slices were cut in this solution with a vibrating tissue slicer (Vibratome 1000 Plus 102; Pelco International) and incubated in a standard artificial CSF (normal ACSF) containing the following (in $\mathrm{mm}$ ): $\mathrm{NaCl} \mathrm{125,} \mathrm{KCl} 2.5$, $\mathrm{NaHCO}_{3} 25, \mathrm{NaH}_{2} \mathrm{PO}_{4} 1.25, \mathrm{CaCl}_{2} 2.0, \mathrm{MgCl}_{2} 1.0$, and D-glucose 25 bubbled with the same mixed gas at $32^{\circ} \mathrm{C}$ for at least $1 \mathrm{~h}$.

Whole-cell recordings. Slices were perfused with gas-saturated ACSF at $2-3 \mathrm{ml} / \mathrm{min}$ at $32^{\circ} \mathrm{C}$. Both the location and shape of each cell were visualized using an upright microscope (BX50WI; Olympus) equipped with an infrared CCD camera (C2741-79; Hamamatsu Photonics). TC cell bodies, which are located within the GL or in the GL near the EPL border, were defined as ETCs (Macrides and Schneider, 1982; Shepherd et al., 2004), and their electrophysiological properties were analyzed. ETCs were voltage-clamped in the conventional whole-cell configuration using a patch-clamp amplifier (EPC 9; Heka). Patch pipettes were pulled from borosilicate glass using a two stage vertical puller (PP-830; Narishige). To record $\mathrm{GABA}_{\mathrm{A}}$ receptor-mediated postsynaptic currents $\left(\mathrm{GABA}_{\mathrm{A}}-\mathrm{PSCs}\right)$, the pipettes were filled with high chloride intracellular solution containing the following $(\mathrm{mM})$ : K-gluconate $95, \mathrm{KCl} 50, \mathrm{MgCl}_{2}$ 2, disodium phosphocreatine $10, \mathrm{Mg}$-ATP $2, \mathrm{Na}_{2}$-GTP $0.3, \mathrm{CaCl}_{2} 0.16$, EGTA 3.0, and HEPES 10, pH 7.25 with $\mathrm{KOH}$. The calculated $\mathrm{Cl}^{-}$equilibrium potential was $-23.8 \mathrm{mV}$ at $32^{\circ} \mathrm{C}$. All membrane potentials were corrected for a $7 \mathrm{mV}$ liquid junction potential measured according to the method of Neher (1992). To block AMPA/KA receptor-mediated currents, CNQX $(10 \mu \mathrm{M})$ was added to ACSF.

To record EPSCs, the pipettes were filled with intracellular solution containing the following (in $\mathrm{mm}$ ): $\mathrm{K}$-gluconate $121, \mathrm{KCl} 4, \mathrm{MgCl}_{2} 2$, disodium phosphocreatine 10, Mg-ATP 2, $\mathrm{Na}_{2}$-GTP $0.3, \mathrm{CaCl}_{2} 0.16$, EGTA 3.0, and HEPES 10, pH 7.25 with $\mathrm{KOH}$. Membrane potentials were corrected for a $13 \mathrm{mV}$ liquid junction potential. To block $\mathrm{GABA}_{\mathrm{A}}$ receptor-mediated currents, picrotoxin $(50 \mu \mathrm{M})$ was added to ACSF.

Light stimulation. A lentiviral vector carrying the 5T4p-Cre construct was injected into both LVs and OBs from Ai32 heterozygous mice (Madisen et al., 2012) at P1. After 4-7 weeks (P28-P49), acute slices were prepared and subjected to recording light-evoked $\mathrm{GABA}_{\mathrm{A}}-\mathrm{PSC}$. For photostimulation, a $455 \mathrm{~nm}$ LED lamp (M455F1; ThorLabs) controlled by an LED driver (DC2100; ThorLabs) was used to irradiate with light a circular region with a radius of $100 \mu \mathrm{m}$ through a $40 \times$ objective lens (LUMPlanFI/IR; Olympus). The intensity of the light was measured by an optical power meter (3664; Hioki) equipped with an adapter (IX3EXMAD; Olympus). To activate 5T4 GCs expressing ChR2-EYFP, either a portion between the surface and intermediate EPLs for recording an ETC or a portion between the bottom of the MC layer and the surface of the GC layer for recording an MC was irradiated by light (10-15 ms in duration) at a dose of $10.6 \mathrm{~mW} / \mathrm{mm}^{2}$ in the presence of an $800 \mathrm{~mA}$ driving current.

Electrical stimulation. Electrically evoked $\mathrm{GABA}_{\mathrm{A}}-\mathrm{PSC}$ s were recorded under the same conditions as for light-evoked $\mathrm{GABA}_{\mathrm{A}}-\mathrm{PSC}$. $\mathrm{GABA}_{\mathrm{A}}$ PSCs were evoked by applying constant current stimuli $(200 \mu \mathrm{s}$ in duration) using a bipolar platinum electrode ( $50 \mu \mathrm{m}$ in diameter, coated with urethane), which was arranged between the surface and intermediate EPLs for recording an ETC or between the bottom of the MC layer and the surface of GC layer for recording an MC. Stimulus intensity was increased in steps of $2 \mu \mathrm{A}$ from the threshold up to $20 \mu \mathrm{A}$, the stimulation intensity of which did not activate the recorded ETC or MC directly. At each stimulus intensity, $>20$ stimuli were delivered at an interval of $5 \mathrm{~s}$. The threshold was defined as the stimulus current at which PSCs having an amplitude of $>25 \mathrm{pA}$ were elicited at a success rate of $25 \%$ or more. To study the effect of a single GC on its interacting ETCs or MCs, recordings containing PSC waveforms with a multitiered fall were dis- carded from the analysis because these waveforms appeared to be a summation of two or more PSCs derived from different GCs. Because the amplitudes of electrically evoked $\mathrm{GABA}_{\mathrm{A}}$-PSCs varied considerably from cell to cell, a Mann-Whitney rank-sum test was performed to test for statistical significance.

Electrically evoked EPSCs were recorded at a holding potential of -80 $\mathrm{mV}$. In $5 \mathrm{~T} 4^{-1-}$ OB slices, GCs were recorded using a pipette solution containing $100 \mu \mathrm{m}$ fluorescein digalactoside (FDG). LacZ-positive GCs, namely 5T4-derived GCs, were identified by fluorescence thorough the hydrolysis of FDG after establishing a whole-cell configuration. In WT OB slices, 5T4 GCs were identified by whole-mount immunostaining with 5T4 antibody after recording the cells. To record a 5T4 GC, the bipolar platinum electrode was arranged between the deep GL and the superficial EPL to stimulate ETCs. The stimulation procedure was similar to that for electrically evoked $\mathrm{GABA}_{\mathrm{A}}$-PSCs except for the threshold criteria. Because distinct and stable EPSCs with an amplitude of $<25 \mathrm{pA}$ were observed frequently in many GCs, the threshold was defined as the stimulus current at which EPSCs having an amplitude of $>10 \mathrm{pA}$ were elicited at a success rate of $25 \%$ or more.

Cell labeling. The internal solution usually contained $1.5 \%$ biocytin for morphological examinations. After pipette withdrawal, slices were fixed in $4 \%$ paraformaldehyde in $0.1 \mathrm{~m}$ PBS overnight. After overnight permeabilization with $0.25 \%$ Triton X-100 in PBS, slices were incubated with streptavidin-conjugated Alexa Fluor 488 (diluted 1:300 with PBS containing $0.1 \%$ Triton X-100) for $6 \mathrm{~h}$. The slices were then rinsed and mounted in Vectashield (Vector Laboratories). The biocytin-labeled cells were imaged with a confocal laser scanning microscope (FV1000; Olympus).

Whole-mount immunostaining. Fixed slices were pretreated as described previously (Renier et al., 2014) with some modifications. Briefly, slices were washed in PBS for 30 min twice, then in 50\% methanol (in PBS) for $10 \mathrm{~min}, 80 \%$ methanol for $10 \mathrm{~min}$, and $100 \%$ methanol for 30 min twice. After overnight bleaching with $5 \% \mathrm{H}_{2} \mathrm{O}_{2}, 20 \%$ DMSO (in methanol) at $4{ }^{\circ} \mathrm{C}$, slices were washed in $100 \%$ methanol for $10 \mathrm{~min}$, then in $20 \%$ DMSO (in methanol) for $30 \mathrm{~min}, 80 \%$ methanol (in PBS) for 10 $\mathrm{min}, 50 \%$ methanol for $10 \mathrm{~min}$, and PBS for $30 \mathrm{~min}$. Slices were incubated in 20\% DMSO, $0.3 \mathrm{M}$ glycine in PBS containing $0.2 \%$ Triton X-100 (PBST) at $37^{\circ} \mathrm{C}$ overnight and blocked with $10 \%$ horse serum in PBST for $2 \mathrm{~h}$. Pretreated slices were incubated with sheep anti-5T4 antibody (1: 1000; R\&D Systems), diluted with $1 \%$ horse serum, $0.01 \%$ sodium azide in PBST for $16 \mathrm{~h}$ at room temperature. After washing with PBST for $8 \mathrm{~h}$, slices were incubated with the secondary antibodies (Jackson ImmunoResearch) for $16 \mathrm{~h}$ at room temperature. After washing with PBST for $8 \mathrm{~h}$, slices were mounted and observed under a confocal laser scanning microscope (FV1000; Olympus).

Food-finding behavior test. A food-finding behavior test was performed to assess the general ability for olfactory detection, as described previously (Le Pichon et al., 2009) with some modifications. Briefly, before testing, mice were fasted in their home cage for $12 \mathrm{~h}$ and 3 successive trials were conducted at $1 \mathrm{~h}$ intervals. In the first and second trials, a food pellet was buried at the same position under the bedding $(5 \mathrm{~cm}$ in depth $)$ at one side of the test cage $(31 \times 25 \times 12.5$ $\mathrm{cm})$. The time taken by the mouse to retrieve the food pellet was recorded. The third trial was conducted without a food pellet and the investigation time in each area during the $2 \mathrm{~min}$ test was measured. To explore the effect of the background odorant on olfactory detection ability, a food-finding behavior test was performed in the presence of a food-unrelated odorant, amyl acetate. Undiluted amyl acetate (100 $\mu l$; Nacalai Tesque) was poured onto filter paper in a polystyrene dish $(100 \times 20 \mathrm{~mm})$ with a multiperforated lid, placed on the bedding in the middle of the cage, and then the food-finding behavior test was performed as described above.

Olfactory habituation-dishabituation test. To evaluate the threshold of odor detection, an olfactory habituation-dishabituation test was performed using an olfactometer (Matsumi Group) to regulate the gas flow $(0.5 \mathrm{~L} / \mathrm{min})$ and switch flow between clean air and air with an odor, which was achieved by passing the air through a bottle containing eugenol (Nacalai Tesque). The olfactometer, connected to the test cage $(31 \times 25 \times 12.5 \mathrm{~cm})$, supplied either the clean air or the 
odor through the gas port $(0.5 \mathrm{~mm}$ diameter hole $)$ on the wall $(2 \mathrm{~cm}$ height). This test was performed under the weak-light condition $(<5$ lux). First, the clean air was supplied to the test cage, to which mice had been habituated for $15 \mathrm{~min}$. In the first trial, mice were exposed continuously to the air for $3 \mathrm{~min}$. In the second trial, the air flow was switched and the mice were exposed to the odor for $3 \mathrm{~min}$. Investigation times in the first and second trials were measured during the 3 min test. "Investigation time" was defined as the time when the nose entered the $2.5 \mathrm{~cm}^{2}$ square area near the gas port.

Odor discrimination learning test. An odor discrimination learning test was performed with 6- to 10-week-old (P42-P70) WT and 5T4 KO mice, as described previously (Imayoshi et al., 2008; Yoshihara et al., 2014) with some modifications (see Fig. 4A). Briefly, mice were food restricted to maintain $80 \%$ of their free feeding weights and trained for $6 \mathrm{~d}$ to associate one of two odorants (odor A and odor B) with a sugar reward. During the training, the odorant was set in a polystyrene dish $(100 \times 20 \mathrm{~mm})$ with a multiperforated lid and placed on the bedding in the middle of the cage $(26 \times 40 \times 18 \mathrm{~cm})$. Several pieces of crystal sugar were put on the lid of the dish containing the rewarded odorant. Mice performed four $10 \mathrm{~min}$ trials per day: two trials for odor A paired with the sugar reward and two trials for odor B unpaired with the sugar reward. On days 5-7, mice received 3 different tests: on day 5 , the 2 test odorants in the dish were placed separately under the bedding $(5 \mathrm{~cm}$ depth) without sugar on each side of the cage $(26 \times 40 \times 18 \mathrm{~cm})$; on days 6 and 7 , only 1 test odorant was placed under the bedding without sugar on 1 side of the cage (day 6 odor A; day 7 odor B). Behaviors were recorded with a digital video camera to measure the time (in seconds) spent by mice in digging for each odorant during the $5 \mathrm{~min}$ test. On days 5 and 6 , mice were trained after receiving the above tests. The following odorants ( $20 \mu \mathrm{l} \mathrm{each})$ were used: odor pair \#1, eugenol $(6.3 \mathrm{M})$ and pentanol $(9.2 \mathrm{M})$ (Nacalai Tesque); odor pair \#2, (+) carvone $(6.4 \mathrm{M})$ and $(-)$ carvone $(6.4 \mathrm{M})$ (Tokyo Chemical).

Object recognition test. To evaluate recognition memory, an object recognition test was performed as described previously (Bevins et al., 2006; Breton-Provencher et al., 2009). First, mice were familiarized with the test cage $(31 \times 25 \times 12.5 \mathrm{~cm})$ for $10 \mathrm{~min}$ and then returned to their home cage. One hour later, in the habituation phase, two identical objects (object A; metal nut) were placed on both sides of the test cage. The time spent exploring each object was recorded for $10 \mathrm{~min}$. We considered the animal to be exploring when its mouth, nose, or paws were in direct contact with the object. The mice were then returned to their home cages. One hour later, in the test phase, two different objects were presented: the familiar object (object A) and a novel object (object B; metal bolt). The time exploring each object was recorded for $5 \mathrm{~min}$. The two objects with distinct features are easily distinguishable from each other by nonolfactory cues such as vision and touch.

Olfactory avoidance test. An olfactory avoidance test was performed as described previously (Kobayakawa et al., 2007; Kaneko-Goto et al., 2013 ) with some modifications. To habituate the mice to the experimental environment, individual mice were placed in a cage $(31 \times$ $25 \times 12.5 \mathrm{~cm}$ ) that was identical to that of the test cage for $30 \mathrm{~min}$ and then transferred to a new cage. This was repeated four times for each animal. In the trial, mice were transferred to the test cage into which a filter paper $(2 \times 2 \mathrm{~cm})$ scented with three different amounts $(0,4$, and $40 \mu \mathrm{l}$ ) of nondehydrogenated 2,4,5-trimethylthiazole (nTMT; Tokyo Chemical) was introduced. This test was performed under the weak-light condition $(<5 \mathrm{lux})$. Both freezing and avoidance times were measured during the 10 min test. "Freezing time" was defined as the time that the mice kept still for $>3$ s except for breathing. "Avoidance time" was defined as the time spent in an area without a filter paper scented with nTMT, when the test cage was divided into two equal areas. Avoidance behavior was represented by an avoidance index as follows: avoidance index $=(P-50) / 50$, where $P$ is the percentage of avoidance time during the 10 min test period.

Statistical analyses. A branching point of dendrites is the point where a neurite extends from the cell body or from another neurite. A branching number of dendrites is the sum of every branching point in a single neuron. All numerical data were analyzed with Microsoft Excel with the add-in software Ekuseru-Toukei 2008 (Social Survey
Research Information). Descriptive statistics were displayed as mean \pm SEM. Student's $t$ test and Mann-Whitney ranked-sum tests were used for pairwise comparisons. Unless otherwise noted, statistical significance for multiple pairwise comparisons was assessed by a one-way or two-way ANOVA, in which homogeneity of variance was verified by Levene's test. Significant ANOVA results were subjected to Tukey's multiple-comparisons test. Differences were deemed significant when $p<0.05$. Behavior tests such as the food-finding test, habituation-dishabituation test, and olfactory avoidance test were assessed using nonparametric statistical analysis because underlying normal distribution and/or variance homogeneity could not be assumed for all the samples. Multiple pairwise comparisons were performed by Welch $t$ test and the resulting $p$-values are shown. $p$-values were then sequentially evaluated according to the Holm-Bonferroni method (Holm, 1979) to keep an experiment-wise $\alpha \leq 0.05$.

\section{Results}

\section{$5 \mathrm{~T} 4$ regulates the dendritic arborization of $\mathrm{OB}$ GCs in a} cell-autonomous manner

We found previously that $5 \mathrm{~T} 4$ regulates dendritic arborization in a specific subtype of OB GCs depending on odor experience (Yoshihara et al., 2012). We injected a lentiviral vector carrying 5T4p-gapEYFP into the LVs of WT and 5T4 ${ }^{-1-}$ mice at P3. This confirmed that 5T4-expressing GCs, termed 5T4 GCs, are a particular subtype of interneuron, the cell bodies of which are located in the MC and superficial GC layers (Fig. 1A). Because $5 \mathrm{~T} 4$ is a transmembrane protein with a leucine-rich repeat extracellular domain, we assumed that it might regulate the morphology of not only 5T4 GCs, but also that of surrounding GCs. We analyzed non-5T4 GCs that did not originate from endogenous 5T4 GCs in 5T4 KO mice. A lentiviral vector carrying CMVp-gapEYFP was injected into the LVs of $\mathrm{WT}$ and $5 \mathrm{~T}^{-1-}$ mice at P3. At P21, the non-5T4 GCs in the superficial GC and MC layers were identified by performing IHC with the 5T4 antibody in WT mice and with the LacZ antibody in $5 \mathrm{~T}^{-1-}$ mice, in which the $5 \mathrm{~T} 4$-coding region was replaced by $L a c Z$ (Southgate et al., 2010; Fig. $1 B$ ). In 5T4 ${ }^{-1-}$ mice, dendrites of LacZ-negative GCs (non-5T4 GCs) had the same branching number as those of non-5T4 GCs in WT mice (Fig. $1 B$ ). In contrast, in $5 T 4^{-1-}$ mice, dendrites of LacZpositive GCs (5T4 GCs) had a smaller branching number than those of 5T4 GCs in WT mice (Fig. 1A). This result indicates that 5T4 regulates the dendritic arborization of 5T4 GCs, but not that of non-5T4 GCs, in a cell-autonomous manner.

Furthermore, in the $5 \mathrm{~T} 4^{-1-} \mathrm{OB}$, we investigated the morphology of projection neurons that form synapses with 5T4 GCs, which exclusively overlap GAD67-positive interneurons (Imamura et al., 2006; Yoshihara et al., 2012). IHC of OB sections showed that the loss of 5T4 did not affect the dendritic pattern of any projection neurons such as TCs (CCK-positive) and MCs (PGP9.5-positive) (Fig. 2B), consistent with the results of Golgi-Cox staining showing no changes in the morphology of ETCs and MCs (Fig. 2C). These results demonstrate that 5T4 specifies the dendritic branching of 5T4 GCs, but not that of their synaptic partners, ETCs and MCs. We also confirmed that the loss of 5T4 did not affect the number of 5T4 GCs (Fig. 2A).

Notably, BrdU labeling of newborn neurons revealed that 5T4 GCs were generated predominantly during the embryonic (E15.5) and neonatal (P0) stages, rather than during the infant (P14) and young stages (P56) (Fig. 1C). This suggested that 5T4 GCs located in the MC and superficial GC layers have a lower turnover rate than other GCs in the deep layer (Fig. 1A). This is supported by previous reports showing that newborn 

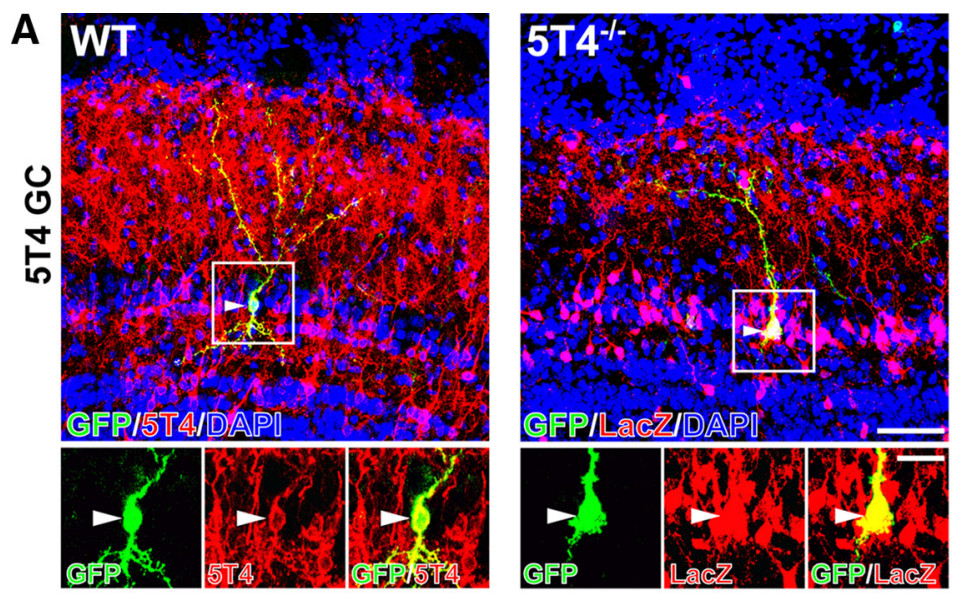

5T4 promoter gapEYFP
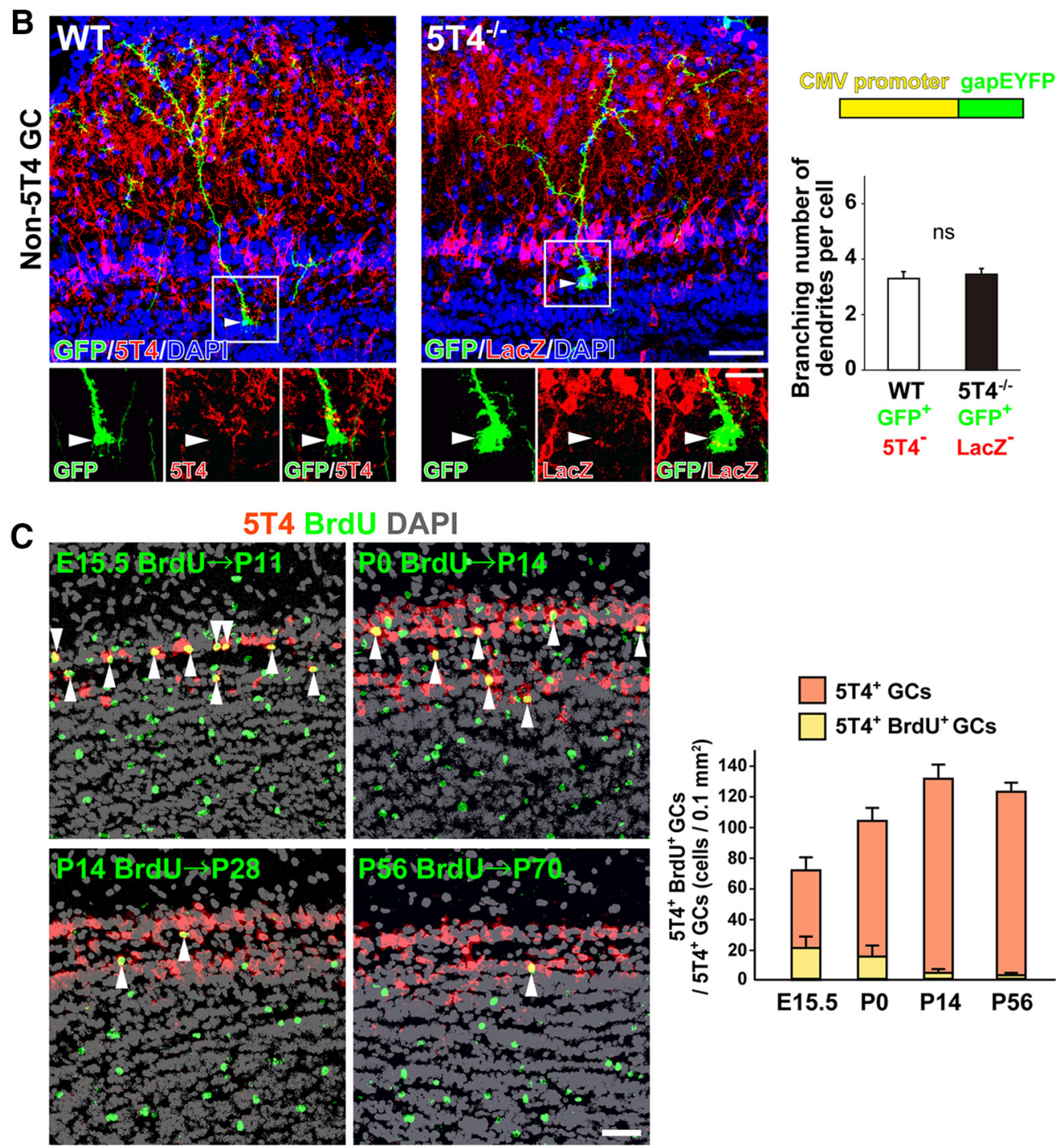

Figure 1. $5 T 4$ affects dendritic development in $5 \mathrm{~T} 4 \mathrm{GCS}$, but not in non-5T4 GCS. $\boldsymbol{A}, \boldsymbol{B}$, Dendritic branching in $5 \mathrm{~T} 4 \mathrm{GCS}(\boldsymbol{A})$ and non-5T4 GCS $(\boldsymbol{B})$. A lentiviral vector carrying $C M V P$-gapEYFP was injected into the LVs of WT and $5 T 4^{-1-}$ mice at P3, and OB sections were immunostained with the GFP antibody (green) and the $5 T 4$ or LacZ antibody (red) at P21. Scale bars, 50 $\mu \mathrm{m}$. Enlarged photos of the area enclosed by a white square in an upper panel are shown below. Scale bars, $20 \mu \mathrm{m}$. White arrowheads indicate the cell bodies of $5 \mathrm{T4} \mathrm{GCS}$ and non-5T4 GCs. Right, The branching number of GC dendrites is expressed as the mean \pm SEM ( $p=0.6511$, ns, and ${ }^{* *} p=0.0002$ between WT and $5 T 4^{-1-}$ mice, Student's $t$ test; $n=20$ cells from three animals of each line). C, IHC and ISH of WT OB sections with the BrdU antibody (green) and $5 T 4$ probe (red), respectively. Scale bar, $40 \mu \mathrm{m}$. Right, Numbers of $5 T 44^{+} \mathrm{GCS}$ and $\mathrm{BrdU}^{+} 5 \mathrm{~T} 4{ }^{+} \mathrm{GCS}$ are shown as the mean $\pm \mathrm{SEM}(n=6$ sections per bar in the graph from 3 animals). Note that $5 \mathrm{~T} 4 \mathrm{GCS}$ are generated mainly during the embryonic (E15.5) and neonatal (P0) stages. 

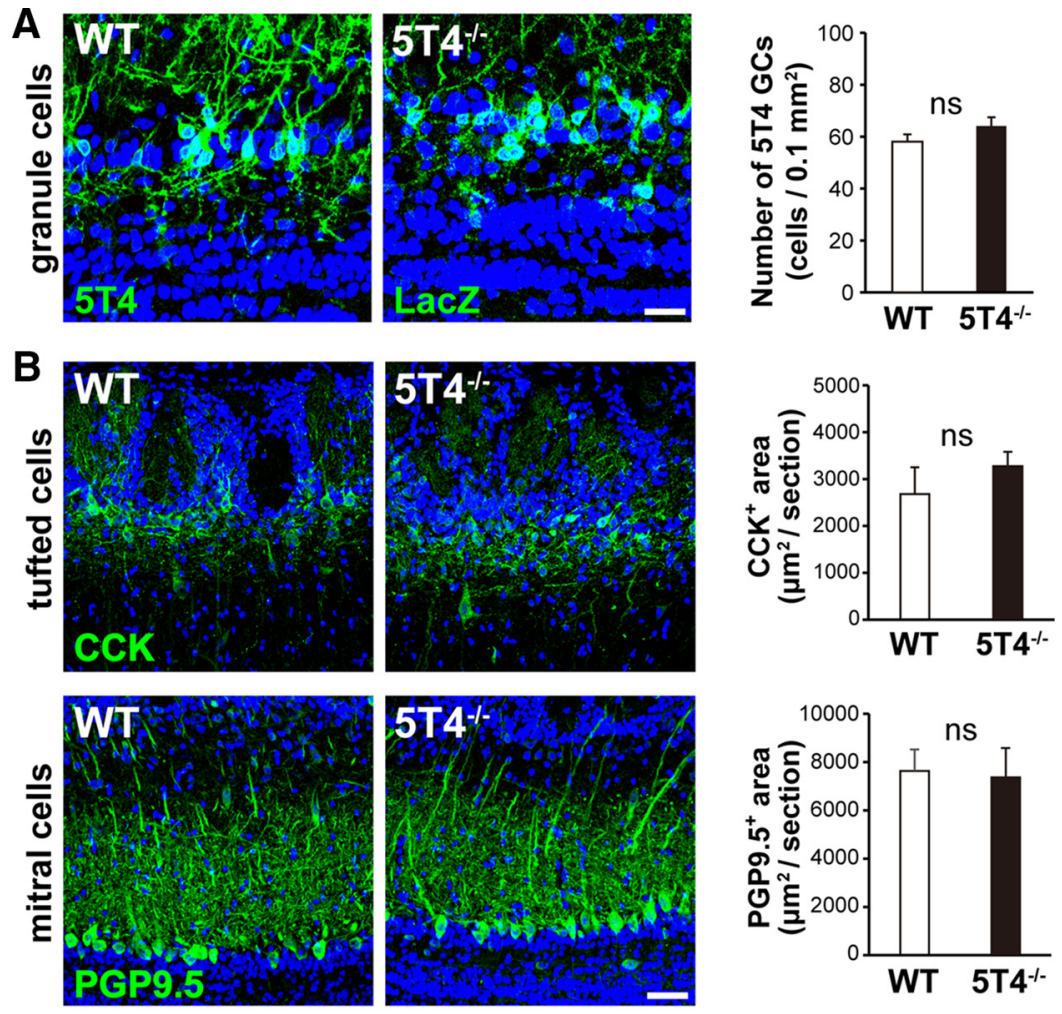

C
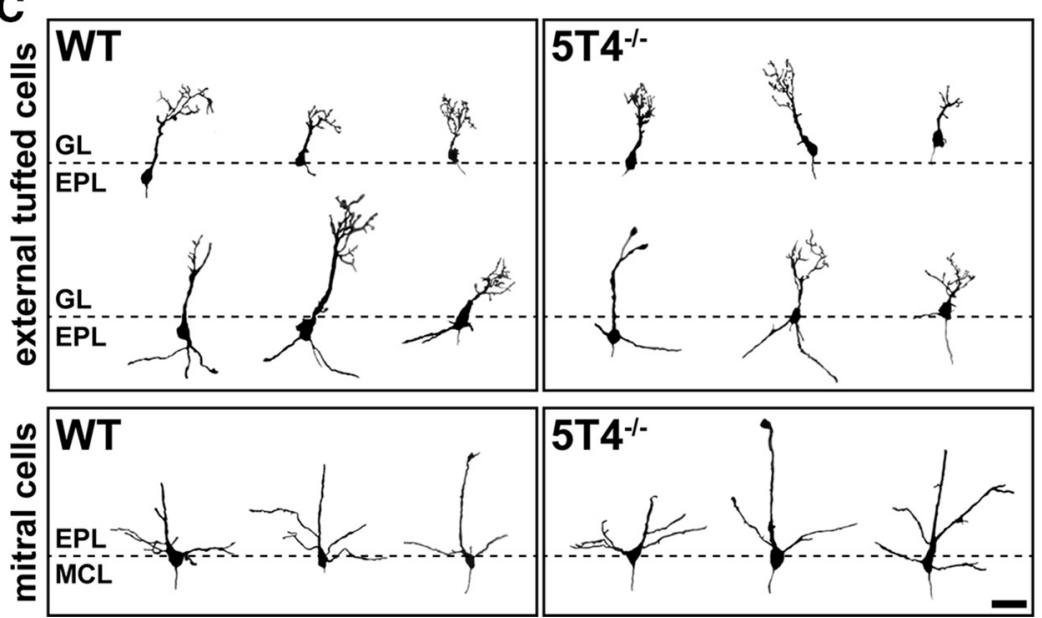

Figure 2. The morphology of $O B$ projection neurons is not affected in $5 T 4 \mathrm{KO}$ mice. $A$, IHC of OB sections from the WT and $5 T 4^{-1-}$ mice at P56 with antibodies against $5 T 4$ and LacZ, respectively. Right, Number of 5T4 GCs (5T4 or LacZ-positive) is expressed as the mean $\pm \operatorname{SEM}\left(p=0.201\right.$, ns, between WT and $5 T 4^{-1}-$ mice, Student's $t$ test; $n=6$ sections per bar from three animals). Scale bar, $20 \mu \mathrm{m} . \boldsymbol{B}, \mathrm{IHC}$ of $0 \mathrm{~B}$ sections from the WT and $5 \mathrm{~T} 4^{-1}-$ mice at P56 with antibodies against cholecystokinin (CCK) and PGP9.5. Scale bar, $40 \mu \mathrm{m}$. Right, Areas of CCK ${ }^{+}$and PGP9.5 $5^{+}$are expressed as the mean \pm SEM $\left[p=0.864\left(C\left(C^{+}\right)\right.\right.$ and $0.392\left(\mathrm{PGP} 9.5^{+}\right.$) between WT and $5 T 4^{-1-}$ mice, Student's $t$ test; $n=6$ sections per bar from 3 animals]. Note that the densities of MCs (PGP9.5-positive) and TCS (CCK-positive) are not remarkably different between WT and 5T4 ${ }^{-1-}$ mice. $\boldsymbol{C}$ Golgi-Cox staining of $\mathrm{OB}$ sections from the WT and $5 \mathrm{~T}^{-1}$ - mice at P56 -P84. GL, glomerular layer; EPL, external plexiform layer; MCL, mitral cell layer. Scale bar, $40 \mu \mathrm{m}$.

OB interneurons at the adult stage are replaced preferentially by old ones in the deep GC layer (Imayoshi et al., 2008; Sakamoto et al., 2014).

Electrophysiological recordings of acute OB slices classify ETCs into two types

Because 5T4 GCs arborize their dendrites into the EPL, where ETCs elongate their lateral dendrites (Mori et al., 1983; Orona et al., 1984), we assumed that 5T4 GCs would form dendro- dendritic synapses preferentially with ETCs (Imamura et al., 2006). Previous studies show that a distinct subpopulation of ETCs have distinct electrophysiological properties and different dendritic branching patterns (Macrides and Schneider, 1982; Antal et al., 2006). To elucidate the relationship between 5T4 GCs and ETCs, we first characterized the electrophysiological properties of ETCs in acute OB slices from WT mice. Interestingly, cell-attached recordings revealed that there are at least two types of ETCs: one type showing periodic bursts of spontaneous firings and another type showing lower spontaneous firing rates than the first type (Fig. $3 A$ ). Based on current-clamp recordings, we defined ETCs with or without a rebound burst firing after the current pulse as bursting or nonbursting ETCs, respectively (Antal et al., 2006; Fig. 3C, asterisk, E). According to this definition, bursting ETCs in WT mice also had a more prominent sag during hyperpolarizing current injection compared with nonbursting ETCs $\left({ }^{* *} p<0.0001\right.$; bursting ETC, $n=17$ cells from 10 animals; nonbursting ETC, $n=20$ cells from 11 animals; Fig. 3C, arrow, $E, F$ ), as reported previously in the rat $\mathrm{OB}$ (Antal et al., 2006). After the electrophysiological recordings, ETC dendrites were visualized by injecting biocytin. Interestingly, there was a remarkable difference in dendrite morphology between bursting and nonbursting ETCs: nonbursting ETCs had basal dendrites extending laterally into the superficial EPL (Fig. 3D), whereas bursting ETCs did not (Fig. 3B).

Next, we investigated the electrophysiological properties of ETCs in the $5 \mathrm{T4} \mathrm{KO}$ mice. As in the case of WT mice, bursting ETCs showed a significantly higher sag ratio than nonbursting ETCs in 5T4 $\mathrm{KO}$ mice ${ }^{* *} p<0.0001$; bursting ETC, $n=17$ cells from nine animals; nonbursting ETC, $n=$ 19 cells from nine animals; Fig. $3 F$ ). There was no significant difference in the sag ratio between WT and 5 T4 $\mathrm{KO}$ mice (Fig. $3 F$ ). These results suggest that the impaired dendritic development of 5T4 GCs does not affect the development of the two ETC types per se in $5 T 4 \mathrm{KO}$ mice, which is consistent with the IHC data for $5 T 4^{-1-}$ OBs (Fig. 2 B, C).

\section{Optogenetic stimulation of ChR2-expressing 5T4 GCs in} OB slices

Next, we used optogenetics to determine which types of projection neurons would form synapses with 5T4 GCs. To induce the expression of the ChR2-EYFP gene in 5T4 GCs, a lentivirus expressing the Cre gene under the control of the $5 T 4$ promoter 
(5T4p-Cre) was injected into both LVs and $\mathrm{OBs}$ of $\mathrm{Ai32}$ (Rosa26-ChR2-EYFP) mice (Madisen et al., 2012) at P1. After 3 weeks, we observed that $73 \%$ of ChR2$\mathrm{EYFP}^{+}$cells were $5 \mathrm{~T} 4 \mathrm{GCs}$, whereas $9 \%$ of 5T4 GCs expressed ChR2-EYFP $(n=4$ sections from 2 animals; Fig. $4 A, B)$. To activate 5T4 GC dendrites, we lightstimulated the superficial, upper half of the EPL in acute OB slices from ChR2EYFP-expressing Ai32 mice and measured light-evoked $\mathrm{GABA}_{\mathrm{A}}$-PSCs in an individual ETC (Fig. 4C). Remarkably, light stimulation of 5T4 GCs induced a $\mathrm{GABA}_{\mathrm{A}}$-PSC in a nonbursting ETC; however, the induction of $\mathrm{GABA}_{\mathrm{A}}$-PSC was inhibited entirely by adding a $\mathrm{GABA}_{\mathrm{A}}$ receptor antagonist, SR95531 (Fig. 4D). Consistent with $9 \%$ of 5T4 GCs expressing ChR2 (Fig. 4B), 7\% of nonbursting ETCs displayed optogenetically evoked PSCs (Fig. 4E). These results indicate that 5T4 GCs form GABAergic synapses with nonbursting ETCs. Furthermore, light stimulation of 5T4 GCs also induced a $\mathrm{GABA}_{\mathrm{A}}$-PSC in a bursting ETC and an MC (Fig. 4E). The mean amplitude of $\mathrm{GABA}_{\mathrm{A}}$-PSCs was indistinguishable among the bursting ETCs, nonbursting ETCs, and MCs (Fig. 4F). These results suggest that 5T4 GC dendrites form GABAergic synapses with, not only nonbursting ETCs, but also bursting ETCs and MCs, to regulate neural activity.

Inhibitory synaptic inputs onto nonbursting ETCs are significantly lower in 5T4 KO mice than in WT mice Because 5T4 GCs form inhibitory synapses with the two types of ETCs and the MCs (Fig. 4), we assumed that the impaired dendritic development of 5T4 GCs in 5T4 KO mice would affect GCderived $\mathrm{GABA}_{\mathrm{A}}$-PSCs in the projection neurons exclusively. To investigate this assumption, we first stimulated the EPL in OB slices with a bipolar platinum electrode and measured electrically evoked $\mathrm{GABA}_{\mathrm{A}}$-PSCs in the two types of ETCs (Fig. 5B, left). To block AMPA/KAreceptor-mediated currents, CNQX (10 $\mu \mathrm{M})$ was added to ACSF. Electrical stimulation of the EPL induced distinctive $\mathrm{GABA}_{\mathrm{A}}$-PSCs in nonbursting ETCs within the WT OB (Fig. 5C). Interestingly, even when the electrical stimulation in the EPL was increased from the threshold by $10 \mu \mathrm{A}$, the amplitude of the $\mathrm{GABA}_{\mathrm{A}}$-PSCs increased only a little (Fig. $5 C, E$ ). In addition, a representative trace of evoked $\mathrm{GABA}_{\mathrm{A}}$-PSCs showed a small fall time (Fig. $5 C$ ) and resembled closely that of spontaneous $\mathrm{GABA}_{\mathrm{A}}$-PSCs (Fig. 5A).

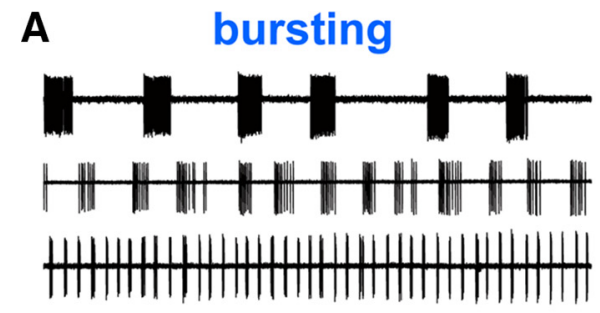

non-bursting
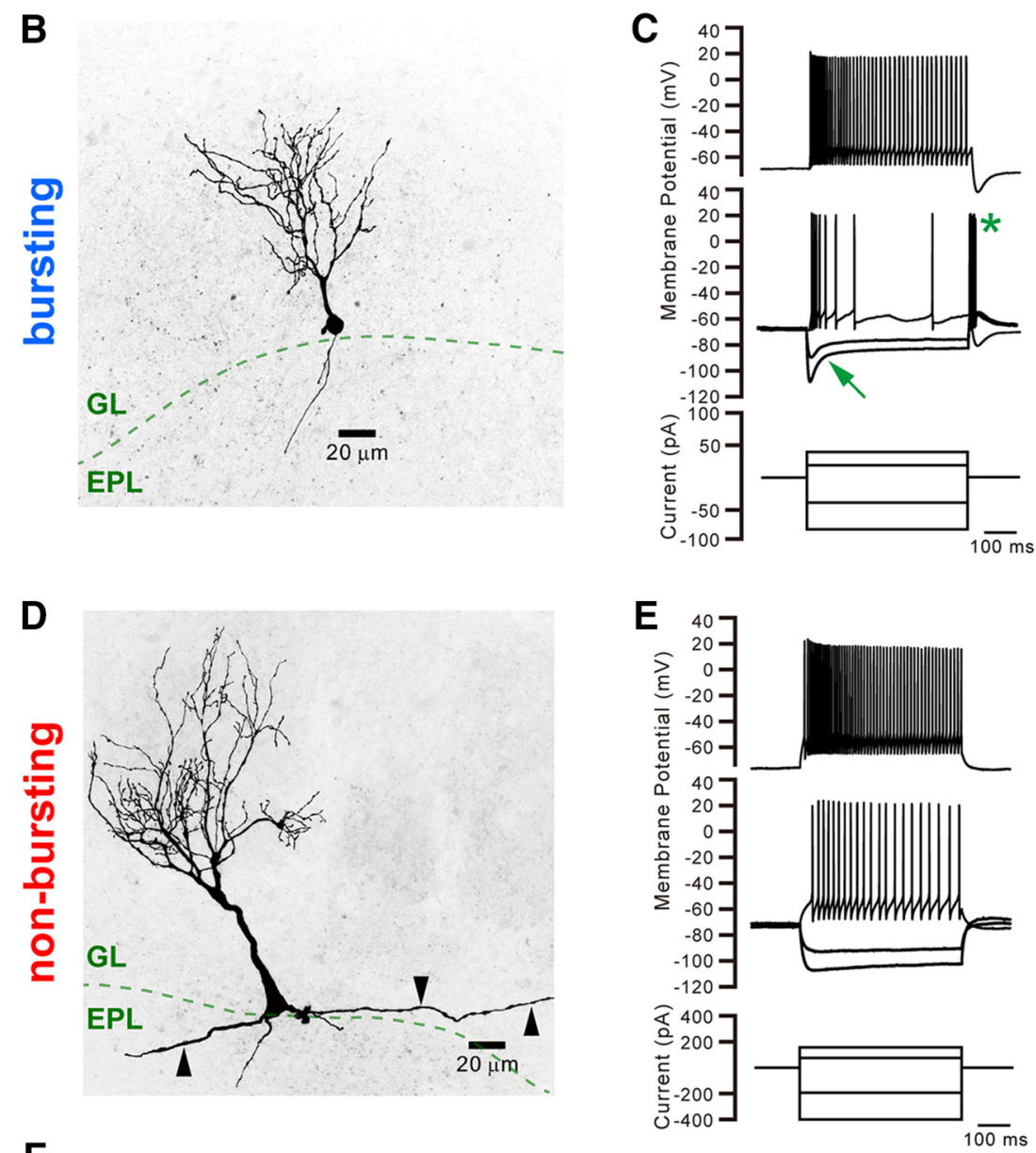

Figure 3. Electrophysiological recordings classify ETCs into two types. $\boldsymbol{A}$, Sample current traces in the cell-attached configuration showing firing bursts recorded from three different bursting and nonbursting ETCs. $\boldsymbol{B}, \boldsymbol{D}$, Two-dimensional projection of morphologies in a biocytin-labeled bursting $(\boldsymbol{B})$ or nonbursting $(\boldsymbol{D})$ ETC. Basal dendrites extending laterally in the superficial EPL are indicated by arrowheads. Scale bars, $20 \mu \mathrm{m}$. $\boldsymbol{C}, \boldsymbol{E}$, Voltage traces in current-clamp mode from the bursting $(\boldsymbol{C})$ and nonbursting $(\boldsymbol{E})$ ETCs shown in $\boldsymbol{B}$ and $\boldsymbol{D}$, respectively. Spike trains elicited by depolarizing current injections showed noticeable accommodation. Voltage responses induced by hyperpolarizing current injections exhibited prominent sags (arrow) upon membrane hyperpolarization and rebound depolarization accompanied by burst firings (asterisk). F, Sag ratios in two types of ETCs from WT and $5 T 4$ KO mice. The bursting ETCs showed a significantly higher sag ratio to $30 \mathrm{mV}$ hyperpolarization than the nonbursting ETCs in both WT and $5 T 4^{-1-}$ OBs $\left(^{* *} p<0.0001\right.$ bursting vs nonbursting ETCs; WT: bursting ETC, $n=17$, nonbursting ETC, $n=20$; $5 T 4$ KO: bursting $\mathrm{ETC}, n=17$, nonbursting $\mathrm{ETC}, n=19)$. 

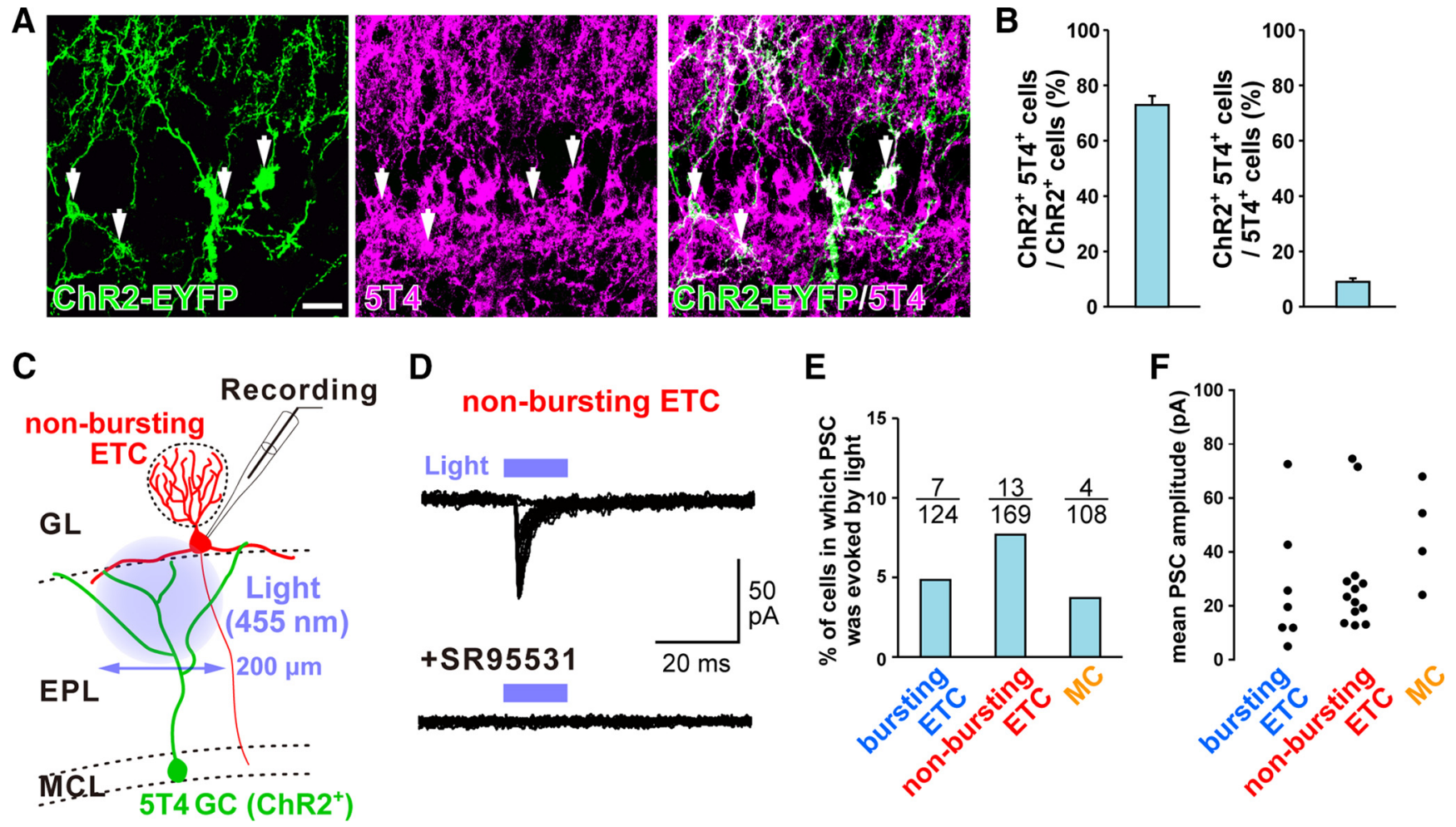

Figure 4. Optogenetic stimulation of ChR2-expressing $5 T 4 \mathrm{GCS}$ in OB slices. A, Expression of ChR2-EYFP in Ai32 mice injected with the 5T4p-Cre lentiviral vector. IHC of OB sections with antibodies against GFP (green) and $5 T 4$ (magenta). Scale bar, $40 \mu \mathrm{m}$. B, Ratios of EYFP ${ }^{+} 5 T 4^{+} \mathrm{GCs}$ in EYFP ${ }^{+}$cells (left) and EYFP ${ }^{+} 5 \mathrm{5T} 4^{+} \mathrm{GCs}_{\text {in }} 5 \mathrm{T4}{ }^{+} \mathrm{GCs}$ (right) are shown as the mean \pm SEM ( $n=6$ sections from 2 animals). C, Schematic diagram of light-evoked GABA $A_{A}-$ PSCs recorded from an ETC. A superficial, upper half of the EPL near the recorded ETC was irradiated by light (10-15 ms in duration) to activate the ramified dendritic tufts of ChR2-expressing GCs. D, Representative traces of light-evoked GABA $-P S C s$ recorded from a nonbursting ETC. Thirteen traces including failures are superimposed. A horizontal bar represents light ( $455 \mathrm{~nm}$ ) irradiation to the EPL. Note that the GABA - -PSCs in nonbursting ETCs (top) were completely abolished by SR95531 (an inhibitor of the GABA $A_{A}$ receptor) (bottom). $E$, Ratios of cells showing light-evoked GABA - PSCs in bursting ETCS, nonbursting ETCS, and MCs. $F$, Distribution of $G_{A B A_{A}-P S C}$ amplitudes in bursting ETCs, nonbursting ETCs, and MCS. Note that the mean amplitudes of GABA $A_{A}-P S C S$ were indistinguishable between the three types.

These results indicated that electrically evoked $\mathrm{GABA}_{\mathrm{A}}-\mathrm{PSCs}$ in nonbursting ETCs were elicited by activation of a few GCs, presumably involving one neuron with processes within the stimulated area under our experimental conditions. Similar results were obtained in bursting ETCs from the WT OB (Fig. 5D).

Because our data suggest that GC dendrites connecting to a single ETC are sparsely distributed in the OB EPL, we investigated GABAergic inputs from a single GC to individual ETCs. We defined $\mathrm{GABA}_{\mathrm{A}}-\mathrm{PSC}$ induced by stimulation with a current 2-4 $\mu \mathrm{A}$ larger than the threshold as the stable minimal response for the ETCs because the current intensity at the threshold sometimes failed to evoke the $\mathrm{GABA}_{\mathrm{A}}$-PSC in individual ETCs (Fig. $5 C ; 12 \mu \mathrm{A})$. We used 20 traces including failures in each current intensity (total 40 traces) to calculate the amplitude of $\mathrm{GABA}_{\mathrm{A}^{-}}$ PSC in individual cells and compared the amplitudes between WT and $5 \mathrm{~T}^{-1-}$ OBs. In bursting ETCs, there was no significant difference in the amplitude of $\mathrm{GABA}_{\mathrm{A}}$-PSCs between WT and $5 T 4$ KO OBs (Fig. 5G). Conversely, in nonbursting ETCs, the median amplitude of $\mathrm{GABA}_{\mathrm{A}}$-PSCs was $29 \%$ lower in $5 T 4 \mathrm{KO}$ than in WT OBs $(p<0.01$, Mann-Whitney rank-sum test; WT, $n=22 ; 5 T 4 \mathrm{KO}, n=21$; Fig. $5 \mathrm{H}$ ). Furthermore, the electrically evoked PSC charge through integration of the waveform for 50 $\mathrm{ms}$ in nonbursting ETCs was also significantly larger in the WT OB than in the $5 T 4^{-1-}$ OB $(p<0.05$, Mann-Whitney rank-sum test; WT, $n=22 ; 5 T 4 \mathrm{KO}, n=21$; Fig. $5 H$ ). These results suggest that the impaired dendritic development of 5T4 GCs in 5T4 KO mice leads to reduced GABAergic inputs into nonbursting ETCs, but not into bursting ETCs. Furthermore, we stimulated the su- perficial GC layer in $\mathrm{OB}$ slices with a bipolar platinum electrode and measured evoked $\mathrm{GABA}_{\mathrm{A}}$-PSCs in an MC (Fig. 5B, right, $F$ ). In MCs, there was no significant difference in the amplitude of $\mathrm{GABA}_{\mathrm{A}}$-PSCs between WT and 5T4 KO OBs (Fig. 5I).

Notably, in the WT OB, nonbursting ETCs showed a $60 \%$ larger amplitude of $\mathrm{GABA}_{\mathrm{A}}-\mathrm{PSC}$ and a $44 \%$ lower coefficient of variation than bursting ETCs (in median value; Fig. 5G,H). It is reported that an increase in the number of synaptic release sites leads to a decrease in the coefficient of variation for the synaptic response amplitude (Faber and Korn, 1991). These results reveal that nonbursting ETCs form more inhibitory synapses with GCs, including 5T4 GCs, than bursting ETCs in the WT OB and thus are more affected by the impaired dendritic development of 5T4 GCs than bursting ETCs in the 5T4 KO OB.

GCs form bidirectional dendrodendritic synapses with projection neurons in the OB (Shepherd et al., 2004). Therefore, in addition to recording inhibitory postsynaptic transmission onto ETCs, we explored postsynaptic transmission in the opposite direction, namely, EPSCs onto 5T4-derived GCs in OB slices of WT and $5 T 4 \mathrm{KO}$ mice (Fig. $6 A-C$ ). Electrical stimulation of the EPL induced distinctive EPSCs in the 5T4 GCs within WT OB slices (Fig. 6D). Intriguingly, we found that 5T4-derived GCs received significantly fewer glutamatergic inputs in 5T4 KO than in WT OBs (Fig. 6E). The median amplitude of EPSCs in 5T4 GCs was $50 \%$ lower in $5 T 4 \mathrm{KO}$ than in WT OBs ( $p=0.0077$, MannWhitney rank-sum test; Fig. $6 E$ ). These results strongly suggest that a combination of reduced inhibitory transmission onto nonbursting ETCs and reduced excitatory transmission onto 5T4 
A

spontaneous

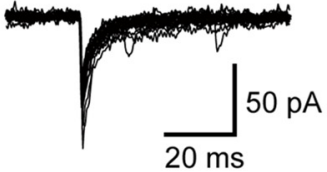

B

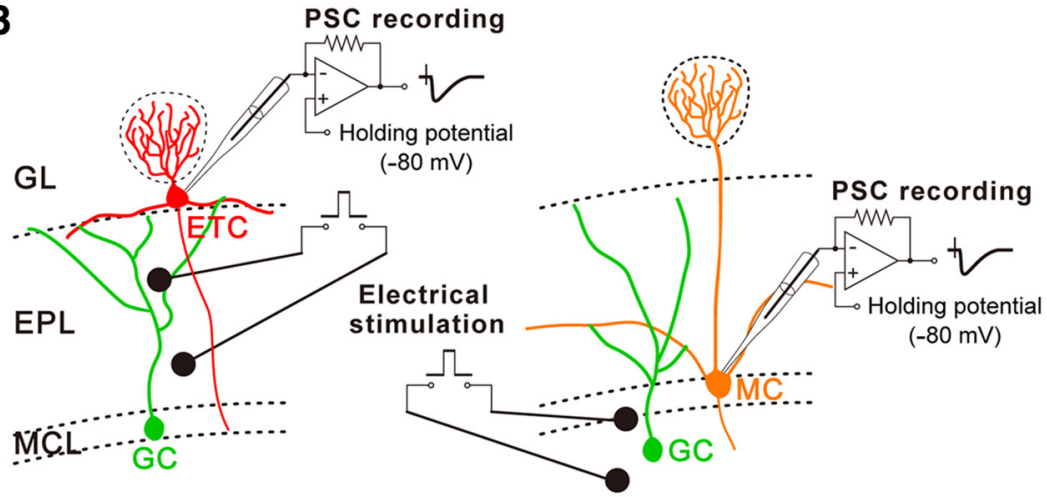

C non-bursting ETC (WVI)

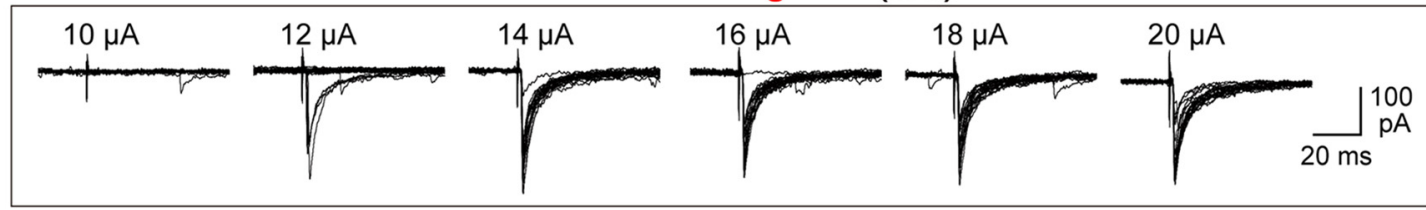

\section{D}

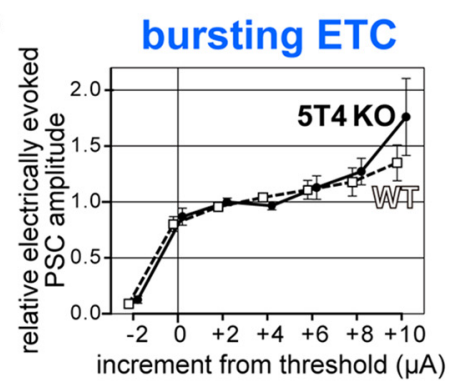

G
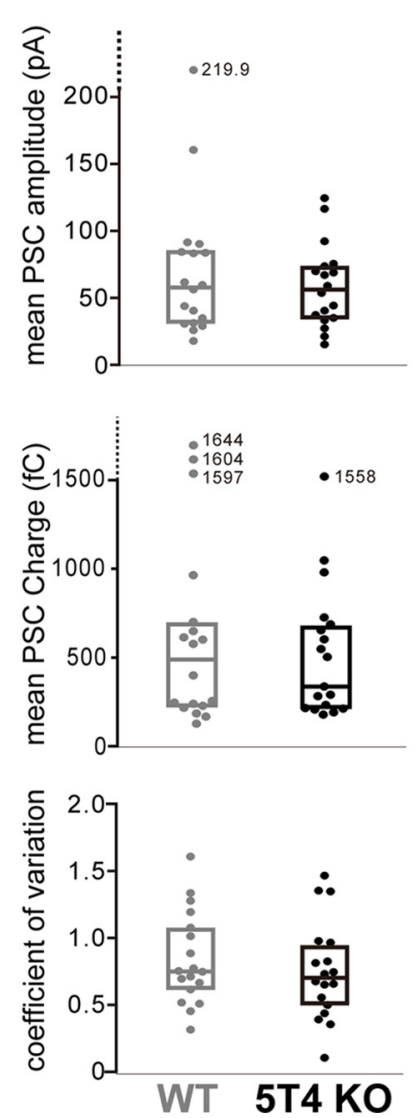

E

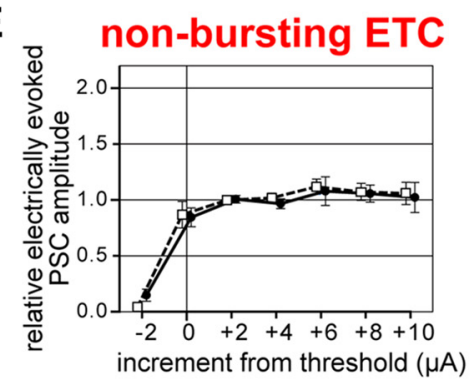

$\mathrm{H}$
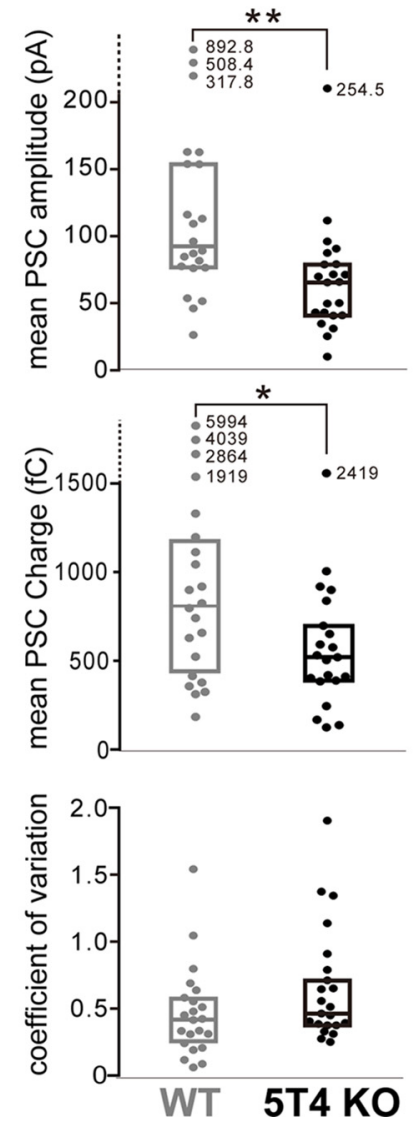

$F$

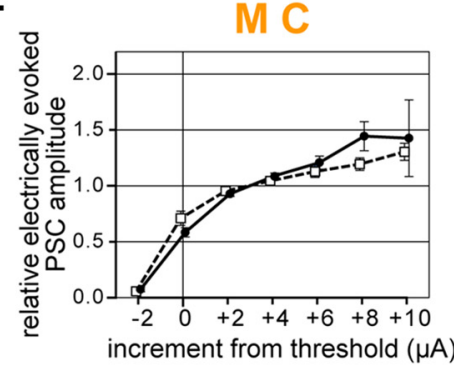

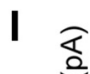

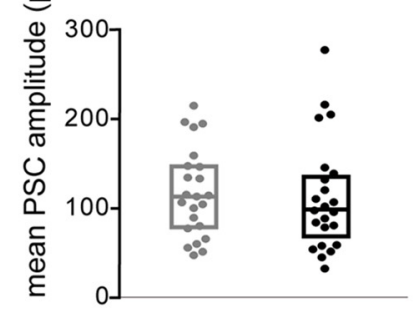

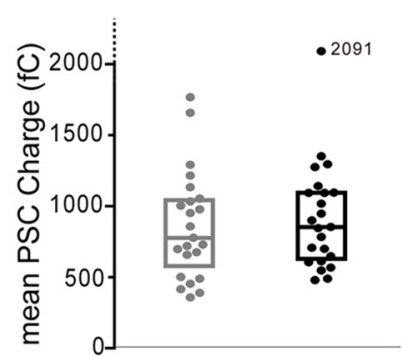

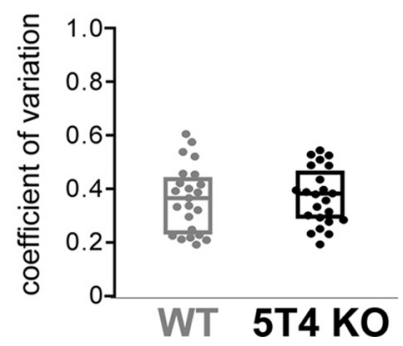

Figure 5. GABAergic inputs are reduced in nonbursting ETCs from $5 T 4 \mathrm{KO}$ mice. $A$, Superimposed traces of spontaneous $\mathrm{GABA}_{\mathrm{A}} \mathrm{PSCS}$ with an amplitude larger than $40 \mathrm{pA}$ recorded from a nonbursting ETCs in WT mice. Each trace is lined up at onset. $\boldsymbol{B}$, Schematic diagram of electrically evoked GABA - PSCs recorded from an ETC (left) or an MC (right). (Figure legend continues.) 
A

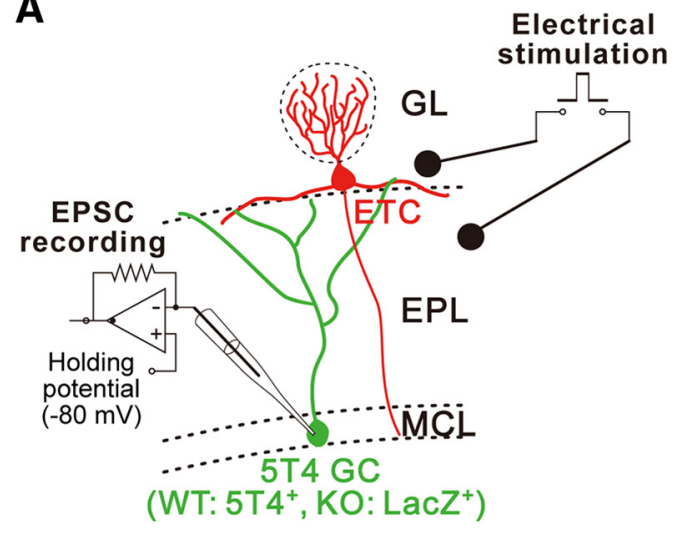

D

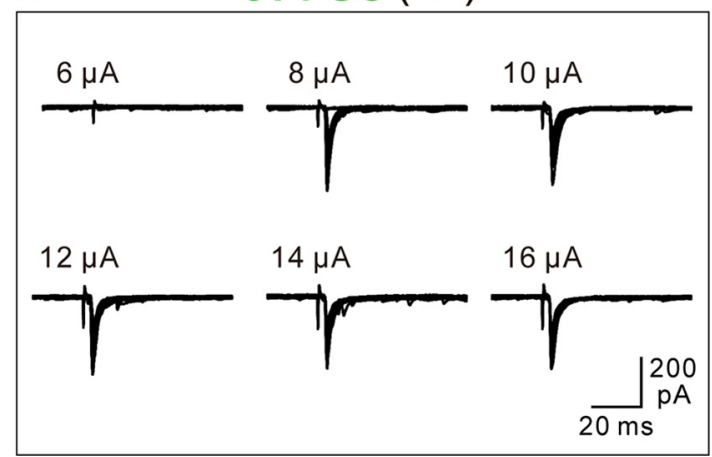

B
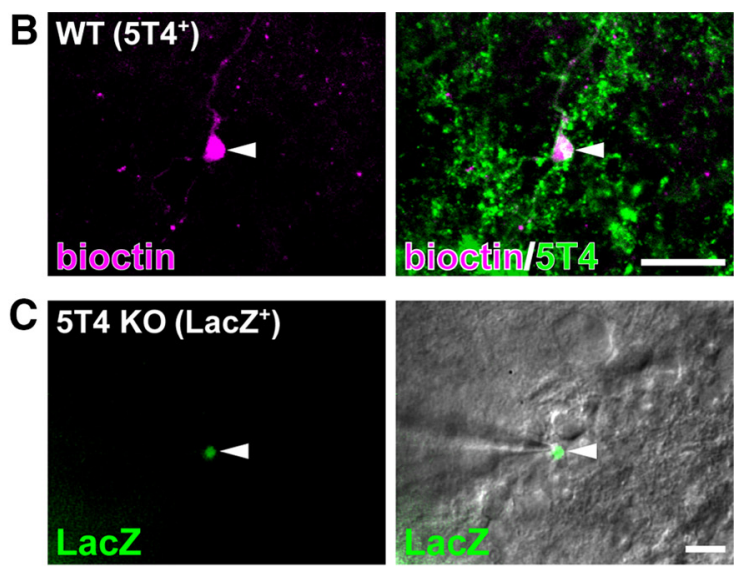

E

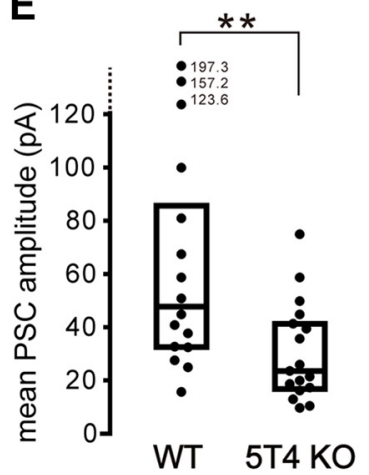

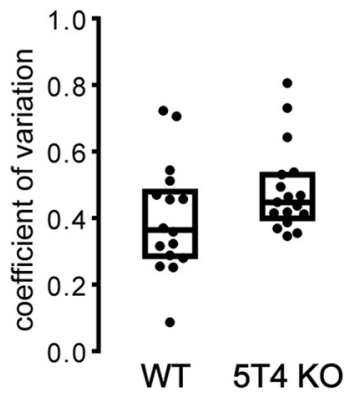

Figure 6. Excitatory inputs are reduced in $5 \mathrm{~T} 4 \mathrm{GCS}$ from $5 T 4 \mathrm{KO}$ mice. $A$, Schematic diagram of electrically evoked EPSCS recorded from a $5 T 4 \mathrm{GC}$. ETCs were stimulated with a constant current (200 $\mu$ s in duration) using a bipolar platinum electrode ( $50 \mu \mathrm{m}$ in diameter) placed in the EPL. Evoked EPSCs were recorded from a $5 \mathrm{~T} 4 \mathrm{GC}$ at a holding potential of $-80 \mathrm{mV}$. B, In WT 0B slices, recorded cells were injected with biocytin (magenta) with a pipette and subjected to whole-mount IHC with the $5 \mathrm{~T} 4$ antibody (green) to identify $5 \mathrm{~T} 4 \mathrm{GCs}$. Scale bar, $20 \mu \mathrm{m}$. C, In $5 T 4{ }^{-1}$ - 0 OB slices, in which cells had been loaded with the LacZ substrate using a recording pipette, LacZ-positive GCs, namely, 5T4-derived GCs, were recorded. Differential interference contrast (right) and fluorescent (left) images of a LacZ-positive GC in the MCL are indicated under the conventional whole-cell configuration. Note that fluorescence became apparent after rupturing the cell membrane. Scale bar, $20 \mu \mathrm{m}$. D, Representative traces of electrically evoked EPSCs recorded at different stimulus intensities $(6-16 \mu \mathrm{A})$ from $5 T 4 \mathrm{GCS}$. For each stimulus intensity, 20 traces are superimposed. $\boldsymbol{E}$, Scatter plots for the mean amplitude (left) and coefficient of variation (right) of electrically evoked EPSCs recorded from 5T4-derived GCs in WT and $5 T 4$ K0 mice $(* * p=0.0077$ WT vs 5 T4 K0 mice, Mann-Whitney rank-sum test; $n=16$ WT and $n=175 T 4 \mathrm{KO}$ cells).

GCs might cause some kind of behavioral change in 5T4 KO mice.

\section{Detection thresholds for odors are higher in $5 T 4 \mathrm{KO}$ mice} Because $5 T 4 \mathrm{KO}$ mice showed significant reductions both in dendrite branching of 5T4 GCs (Fig. 1A) and in synaptic transmission onto ETCs and 5T4 GCs (Figs. 5, 6), we conducted a behavior test to assess olfactory detection in these mice. 5T4 KO mice were born normally and showed no obvious abnormalities

\section{$\leftarrow$}

(Figure legend continued.) GCs were stimulated with a constant current (200 $\mu$ s in duration) using a bipolar platinum electrode ( $50 \mu \mathrm{m}$ in diameter) placed in the EPL. Evoked GABA - PSCs were recorded from an ETC or an MC at a holding potential of $-80 \mathrm{mV}$. C, Representative traces of evoked GABA - PSCs recorded at different stimulus intensities $(10-20 \mu \mathrm{A})$ from the nonbursting ETC. For each stimulus intensity, 20 traces are superimposed. $\boldsymbol{D}-\boldsymbol{F}$, Plots for the amplitude of electrically evoked $G A B A_{A}-$ PSCS versus the stimulus intensity (increment from a threshold current) in bursting ETCS $(\boldsymbol{D})$, nonbursting $\operatorname{ETCS}(\boldsymbol{E})$, and MCS $(\boldsymbol{F})$ between WT (dotted lines) and $5 T 4 \mathrm{KO}$ mice (solid lines). The amplitude of $\mathrm{GABA}_{A}-\mathrm{PSC}$ is expressed as ratios to the mean amplitude of stable minimal PSCs. $\mathbf{G}-\mathbf{I}$, Scatter plots for the mean amplitude (top), integrated charge (center), and coefficient of variation (bottom) of evoked GABA $A_{A}-$ PSCs recorded from bursting $\operatorname{ETS}(\boldsymbol{G})$, nonbursting $\operatorname{ETCS}(\boldsymbol{H})$, and MCs $(\boldsymbol{I})$ in WT and 574 KO mice ${ }^{* *} p<$ $0.01,{ }^{*} p<0.05$ WT vs $5 T 4$ KO mice, Mann-Whitney rank-sum test; bursting ETCs: $n=18$ cells from each line; nonbursting ETCs: $n=22$ WT and $n=215 T 4 \mathrm{KO}$ cells; MCs: $n=23$ cells from each line). Outlying data are shown as individual points with each numerical value. The internal bar and height of the box represent the median and interquartile range, respectively. in mating, nursing, or feeding behavior. Because adult $5 T 4^{-1-}$ mice exhibit a high frequency of hydrocephalus $(\sim 13 \%$; Southgate et al., 2010), we used 6- to 10-week-old male mice (P42-P70) without hydrocephalus in the following experiments. First, using a food-finding test (Le Pichon et al., 2009), we measured the time taken by the fasted mice to find a food pellet hidden under the bedding on one side of the cage. In the first trial, mice retrieving food faster than other mice were assumed to have a better sense of smell. However, there was no difference between WT and 5T4 $\mathrm{KO}$ mice with respect to the time taken to find food in the first trial (Fig. 7A). This result indicated that 5T4 KO mice could detect the smell of food as well as WT mice. In the second trial, with the food pellet buried in the same place as in the first trial, there was no difference in the times taken to find the food between WT and 5T4 KO mice (Fig. 7A). To study the spatial memory of $5 T 4 \mathrm{KO}$ mice, we performed the third trial without the food pellet and measured the time that the mice spent in each side of the cage. Both WT and 5T4 KO mice spent significantly more time near the area where the food pellet had been buried in the first and second trials (Fig. 7A). These results suggest that 5T4 $\mathrm{KO}$ mice can learn and memorize the position of food as well as WT mice.

Next, we used a habituation-dishabituation test to examine odor detection thresholds. Mice were exposed to clean air using an olfactometer and were then provided with air in the first trial. 
Because the mice had been habituated to clean air, the investigation time was shorter in this trial (Fig. $7 B$ ). In the second trial, a test odorant, eugenol, at four different concentrations $(0.63,6.3,63$, and $630 \mu \mathrm{M})$ was presented to the mice. Differences in investigation times between first and second trials were analyzed in WT and $5 T 4 \mathrm{KO}$ mice. At 6.3 and $63 \mu \mathrm{M}$, the investigation time of $5 \mathrm{~T} 4$ KO mice was remarkably shorter than that of WT mice ( $p<0.01$ and 0.05 , respectively; $n=5$ animals in each condition; Fig. $7 B$ ), whereas at $630 \mu \mathrm{M}$, the investigation time of $5 T 4 \mathrm{KO}$ mice was similar to that of WT mice (Fig. $7 B$ ). These results suggest that the odor detection thresholds of $5 \mathrm{~T} 4 \mathrm{KO}$ mice are $>100$-fold higher than those of WT mice.

Furthermore, we performed an olfactory avoidance test (Kobayakawa et al., 2007; Kaneko-Goto et al., 2013). A component of fox feces, TMT (2,4,5trimethylthiazole), evokes innate fear responses in rodents (Vernet-Maury et al., 1984; Fendt et al., 2005). We found that nTMT also induced similar freezing and avoidance responses between WT and $5 T 4 \mathrm{KO}$ mice when a high amount $(40 \mu \mathrm{l})$ was used (Fig. 7C). Interestingly, when a lower amount $(4 \mu \mathrm{l})$ of nTMT was used, WT mice showed significant freezing and avoidance responses compared with 5T4 KO mice (freezing, 20\%; avoidance, $69 \%$; $p<0.01,0.05$, respectively; $n=5$; Fig. $7 C)$. These results strongly suggest that detection sensibility for odors is impaired in $5 T 4 \mathrm{KO}$ mice, which is consistent with the results shown in Figure $7 B$.

However, the results of the habituation-dishabituation test could have been affected by differences in the exploratory behaviors of the mice. Because 5T4 is expressed in other brain regions, including eye, neocortex, amygdala, and inferior colliculus (Imamura et al., 2006; our unpublished data), we performed a novel object recognition test (Fig. 7D) to assess recognition memory and incentive-directed motivation in global 5T4 KO mice (Bevins et al., 2006; Breton-Provencher et al., 2009). After habituating the mice to an object, the mice were exposed to a novel object and the time taken by the mice to explore the object was measured. Although both WT and 5T4 KO mice spent more time exploring the novel object than the familiar one, there was no significant difference between the two mice (Fig. 7D). Therefore, these results confirm that exploratory behavior for object recognition was unaffected in $5 \mathrm{~T} 4 \mathrm{KO}$ mice.
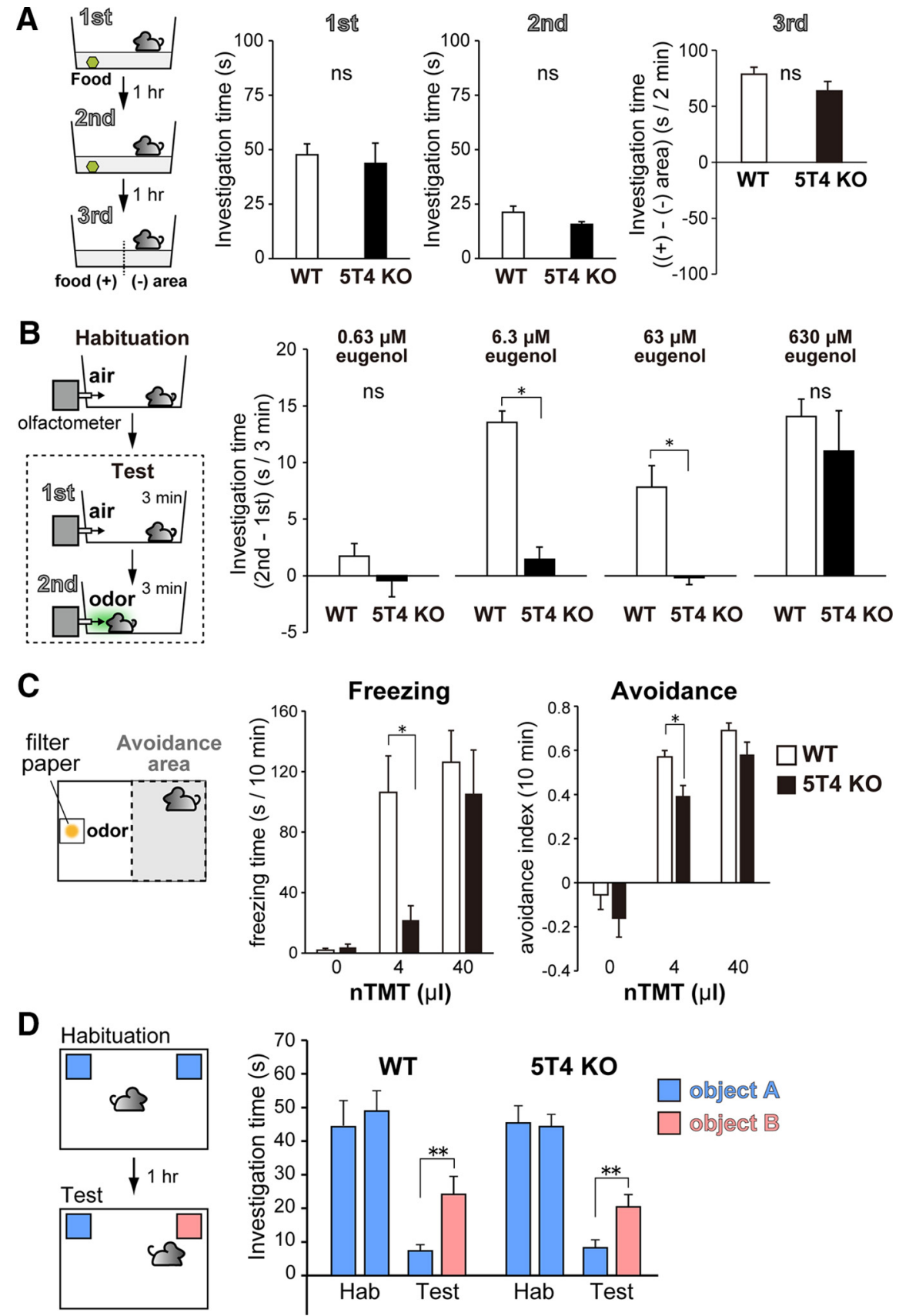

Figure 7. Detection thresholds for odors are higher in $5 T 4 \mathrm{KO}$ mice. $\boldsymbol{A}$, Food-finding test for WT and $5 T 4 \mathrm{KO}$ mice. Center, In the first and second trials, times spent by the fasted mice in finding a food pellet buried at the same position under the bedding on one side of the test cage were measured at $1 \mathrm{~h}$ intervals between the 2 trials. One hour later, the third trial was performed without a food pellet and the investigation time in each area during the 2 min test was measured. Right, Bars depict the difference in time taken by the mice to investigate each area of the cage in the third trial. Note that WT and 5T4 KO mice could not be distinguished based on food-seeking times, expressed as the mean \pm SEM $[p=0.709$, ns. (first), 0.082 (second), and 0.186 (third) $]$ between WT and $5 T 4 \mathrm{KO}$ mice (Welch $t$ test with Holm-Bonferroni correction; $n=7 \mathrm{WT}$ and $n=85 \mathrm{~T} 4 \mathrm{KO}$ animals). $\boldsymbol{B}$, Olfactory habituationdishabituation test for the WT and 5 T4 KO mice. First, clean air was supplied into the test cage and mice were habituated for $15 \mathrm{~min}$. In the first trial, clean air was supplied for $3 \mathrm{~min}$. Differences in investigation times between the first trial and second trial with eugenol are expressed as the mean $\pm \operatorname{SEM}\left[p=0.275\right.$, ns $(0.63 \mu \mathrm{M})$ and $p=0.463(630 \mu \mathrm{M})$; ${ }^{*} p=0.000001$, significant $(6.3$ $\mu \mathrm{M})$ and $p=0.007(63 \mu \mathrm{m})$ ] between WT and $574 \mathrm{~K} 0$ mice (Welch $t$ test with Holm-Bonferroni correction; $n=5$ animals in each condition). C, Olfactory avoidance test for WT and $5 T 4 \mathrm{KO}$ mice. Mice were transferred to the test cage and exposed to a filter paper scented with 3 different amounts $(0,4$, and $40 \mu l)$ of nTMT. Freezing time and avoidance index during the 10 min test are expressed as the mean \pm SEM $\left({ }^{*} p=0.008\right.$ freezing and $p=0.014$ avoidance WT vs $5 T 4$ KO mice; Welch $t$ test with Holm-Bonferroni correction; $n=5$ animals in each condition). D, Object recognition test for WT and 5 T4 K0 mice. Object exploration times for animals presented with either two identical (habituation phase: object A) or two different (test phase: objects $A$ and $B$ ) objects are expressed as the mean \pm SEM $\left({ }^{*} p=0.006 \mathrm{WT}\right.$ and $p=0.0085 \mathrm{~T} 4 \mathrm{KO}$ right vs left objects; Wilcoxon signed-rank test; $n=11 \mathrm{WT}$ and $n=95 \mathrm{~T} 4 \mathrm{KO}$ animals). 
A Experimental time course

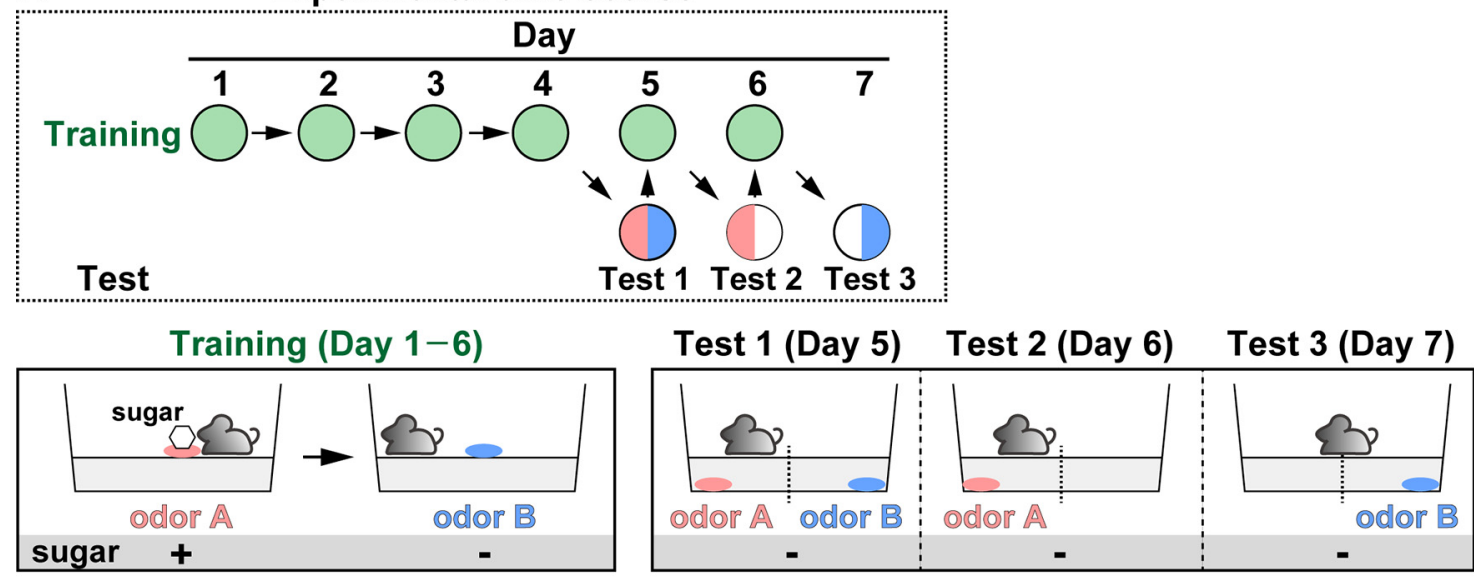

B odor A: eugenol odor B: pentanol<smiles>C=CCc1ccc(O)c(OC)c1</smiles>
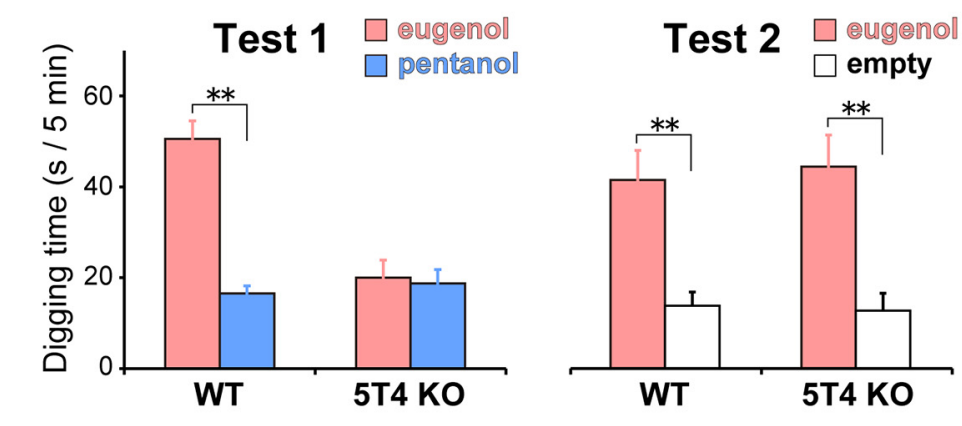

Test $3 \square$ empty

C odor $\mathbb{A}^{(t)}$ ) carvone odor B: (-) Garvone
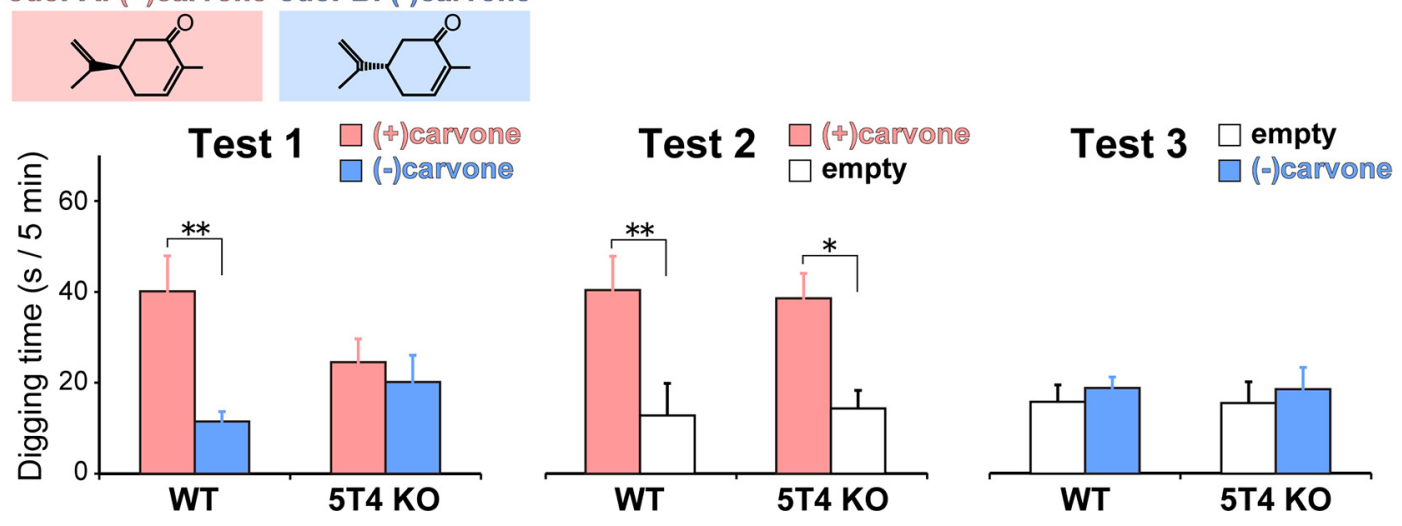

Figure 8. Discrimination learning between two different odors is impaired in $5 T 4 \mathrm{KO}$ mice. $A, 0$ dor discrimination learning test. The top schema indicates the experimental time course. In the training phase on days 1-6, WT and 5T4 KO mice learned to associate the sugar reward with odor A. In the test phase on days 5-7, the sugar reward was removed from odor A, followed by odor discrimination learning (Tests $1-3$ ). The time taken by the mice to dig at each side of the test cage was measured. $\boldsymbol{B}$, Digging times during the 5 min test (Tests $1-3$ ) are represented as bar graphs: eugenol paired with the sugar reward (red) and pentanol unpaired (blue). In Tests 2 and 3, digging times in the area without odors (white bars) are expressed as the mean \pm SEM $\left({ }^{* *} p=0.000001\right.$ Test $1, \mathrm{WT} ; p=0.00001$ Test $2, \mathrm{WT} ; p=0.000006$ Test $2,5 \mathrm{~T} 4 \mathrm{KO}$ between both areas in each test; two-way repeated-measures ANOVA; $n=5$ animals from each line). C, Digging times during the 5 min test (Tests $1-3$ ) are represented as bar graphs: $(+)$ carvone paired with the sugar reward (red) and ( -$)$ carvone unpaired (blue). Digging times are expressed as the mean \pm SEM $\left({ }^{* *} p=0.001\right.$ Test 1, WT; $p=0.008$, Test 2 , WT; ${ }^{*} p=0.0169$, Test $2,5 T 4$ KO between both areas in each test; two-way repeated-measures ANOVA; $n=5$ animals from each line).

Odor discrimination learning is impaired in $5 T 4 \mathrm{KO}$ mice We investigated whether dendritic development in OB GCs would be required for odor discrimination learning and memory (Imayoshi et al., 2008). We compared the performances of WT and 5T4 KO mice at 6-10 weeks of age (P42-P70) in an odor discrimination learning test using two undiluted odorants. Mice were trained for days $1-4$ to associate an odorant, eugenol, with a sugar reward (Fig. 8A). During the training, 5T4 KO mice con- sumed sugar at a similar level to that of WT mice $(\mathrm{WT}=0.15 \pm$ $0.01 \mathrm{~g} / \mathrm{d} ; 5 T 4 \mathrm{KO}=0.13 \pm 0.01 \mathrm{~g} / \mathrm{d} ; p>0.05 ; n=8$ animals from each line; Fig. $8 A$ ). On day 5 (Test 1), we placed two odorants, eugenol and pentanol, separately underneath the bedding without any sugar and measured the time the mice spent digging near each odor. WT mice spent significantly more time digging near eugenol than near pentanol $(p<0.05 ; n=5$; Fig. $8 B)$, whereas $5 T 4 \mathrm{KO}$ mice spent nearly the same time digging for eugenol and 


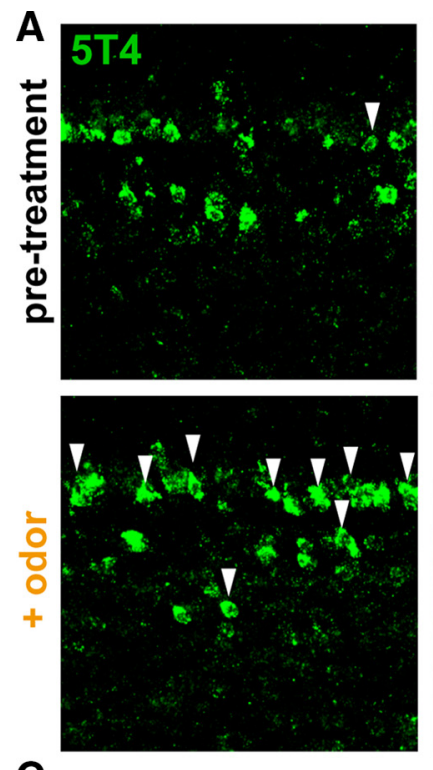

C

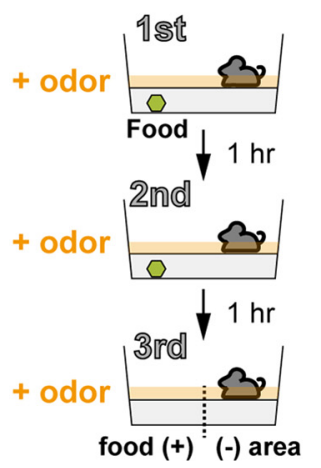

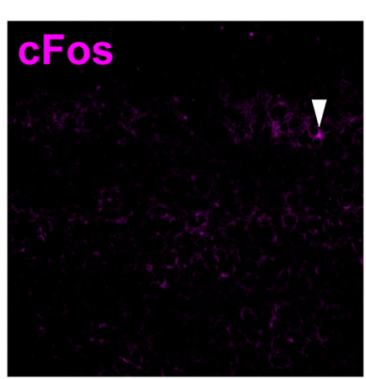
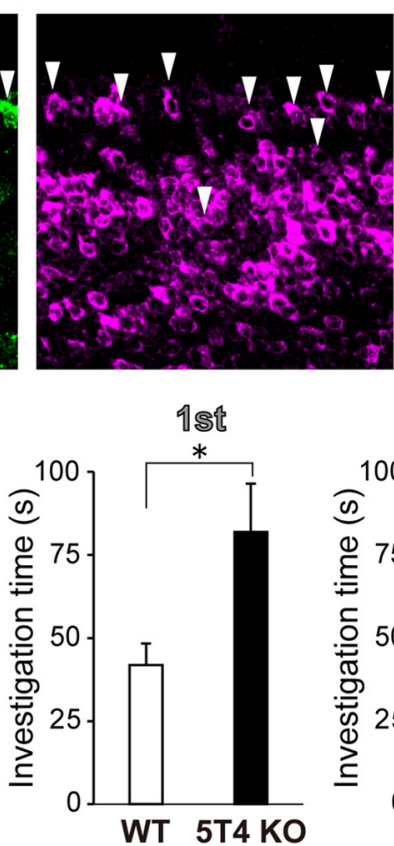

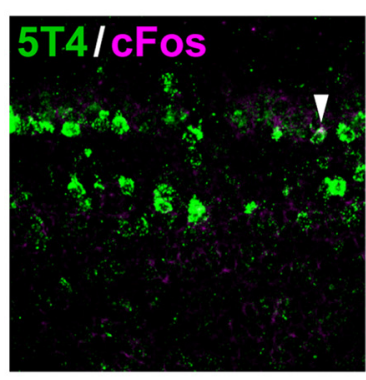

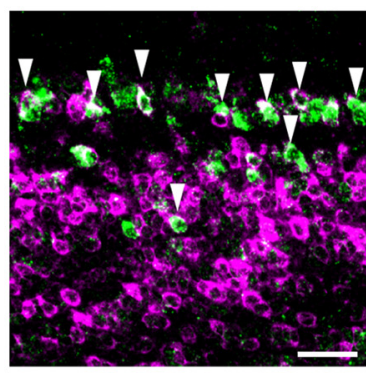

2nd
B

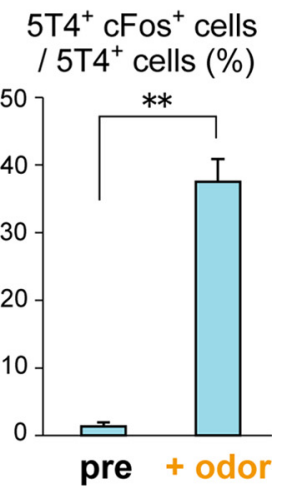

3rd

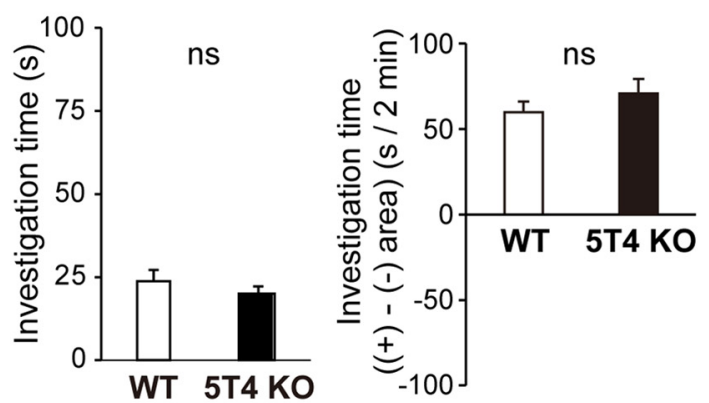

Figure 9. $5 T 4 \mathrm{KO}$ mice cannot discriminate food odor in the presence of a background odor. $A$, Double ISH with RNA probes to $5 T 4$ (green) and cFos (neuronal activity marker, magenta) genes in OB sections from P21 odor-stimulated mice. CFos expression was induced immediately in $5 \mathrm{~T} 4 \mathrm{GCS}$ after stimulation with the odorant amyl acetate for 30 min. Scale bar, $40 \mu \mathrm{m}$. B, Ratios of cFos ${ }^{+}$ $5 \mathrm{~T} 4{ }^{+} \mathrm{GCs}$ in $5 \mathrm{~T} 4{ }^{+} \mathrm{GC}$ are shown as the mean $\pm \mathrm{SEM}\left({ }^{* *} p=0.00009\right.$ vs pretreatment condition, Student's $t$ test; $n=6$ sections per bar from three animals). $C$, Food-finding test was performed in the presence of the food-unrelated odorant amyl acetate. Center, In the first and second trials, the times taken by the fasted mice to find a food pellet buried at the same position under the bedding in one side of the test cage were measured at a $1 \mathrm{~h}$ interval between them. One hour later, the third trial was performed without a food pellet and the time spent by the mice in each side of the cage was measured during the 2 min test. Right, Bars depict the difference in time taken by the mice to investigate each area of the cage in the third trial. Compared with WT mice, $5 T 4$ K0 mice needed longer food-seeking times, which are expressed as the mean \pm SEM $\left[p=0.371\right.$, ns (second); $p=0.426$ (third); ${ }^{*} p=0.010$ between WT and $5 T 4$ KO mice, Welch $t$ test with Holm-Bonferroni correction; $n=13 \mathrm{WT}$ and $n=85 \mathrm{~T} 4 \mathrm{~K} 0$ animals).

pentanol (Fig. 8B). These results indicate that the loss of $5 T 4$ impairs odor discrimination learning.

Because the odor detection thresholds were remarkably higher in 5 T4 KO mice (Fig. $7 B, C$ ), it was uncertain whether these mice could detect odorants buried under the cage bedding in Test 1 . To address this issue, we performed additional tests using eugenol and pentanol on day 6 (Test 2) and day 7 (Test 3), respectively. Interestingly, in Test 2, 5T4 KO mice spent significantly more time digging near the area scented with eugenol (associated with the sugar reward) than in the opposite area, as in the case of WT mice $(p<0.05 ; n=5$ animals from each line; Fig. $8 B)$. In contrast, in Test 3, neither WT nor 5T4 KO mice preferred to dig near the area scented with pentanol (not associated with the sugar reward; Fig. $8 B$ ). These results suggested that $5 \mathrm{~T} 4 \mathrm{KO}$ mice could learn that eugenol was the odor associated with sugar during the training phase and detect eugenol buried under the cage bedding in Test 2 . However, 5 T4 $\mathrm{KO}$ mice could not discriminate eugenol when both odors were present in Test 1 , whereas WT mice could. Similar results were obtained in another odor discrimination learning test using a pair of structurally related odors, (+) carvone and (-) carvone (Fig. 8C). These results strongly suggest that 5T4-dependent dendritic development of OB GCs is required for discriminating between two different odors.

To further support this conjecture, we investigated the ability of the mice to discriminate an odor of interest in the presence of a background unrelated odor. Notably, exposure to a high concentration of amyl acetate induced the expression of $c$ Fos (a marker of neuronal activity) in 38\% of 5T4 GCs (Fig. $9 A, B)$. This suggested that the odor signal from amyl acetate was processed by $5 \mathrm{~T} 4 \mathrm{GCs}$ in the broad area of the OB, consistent with our previous data (Yoshihara et al., 2014). There was no significant difference between WT and $5 T 4 \mathrm{KO}$ mice in a normal food-finding test without a food-unrelated odorant such as amyl acetate (Fig. 7A). In contrast, in a food-finding test with amyl acetate, 5T4 KO mice needed more time to find a food pellet in the first trial than did WT mice (Fig. 9C), whereas there was no significant difference between the mice in the second and third trials (Fig. 9C). These results clearly revealed that $5 T 4 \mathrm{KO}$ mice cannot discriminate an odor of interest from a background odor. 

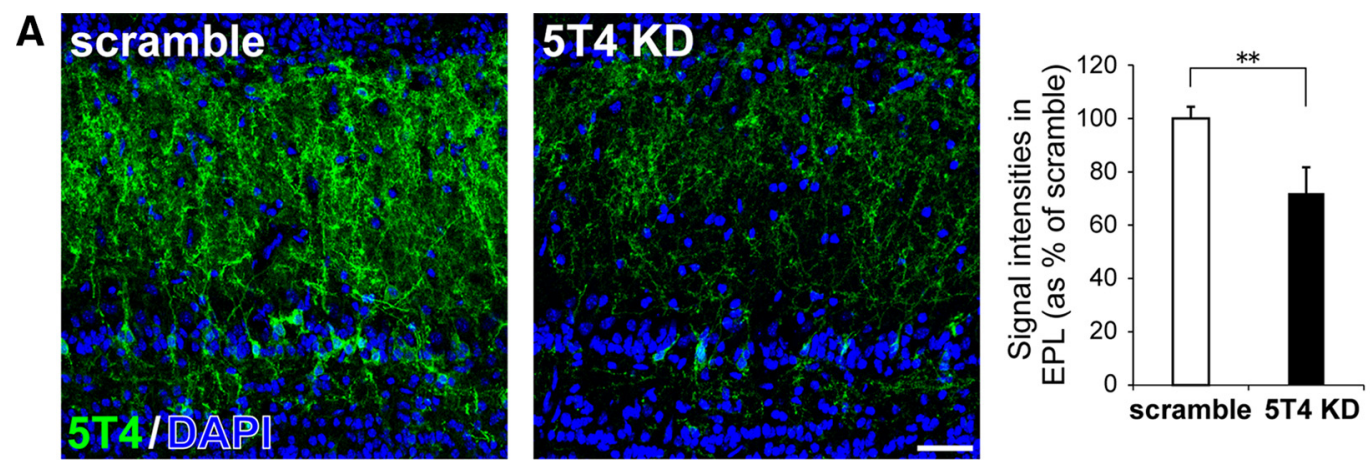

B

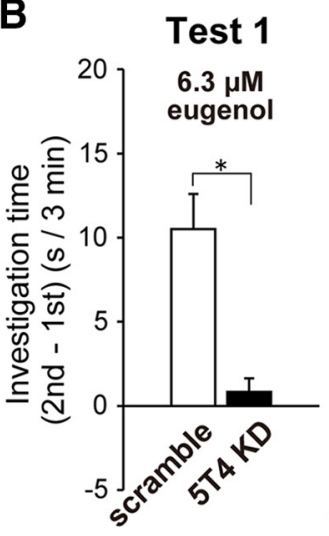

Test 2 $630 \mu \mathrm{M}$ eugenol

ns

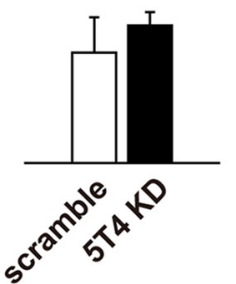

C

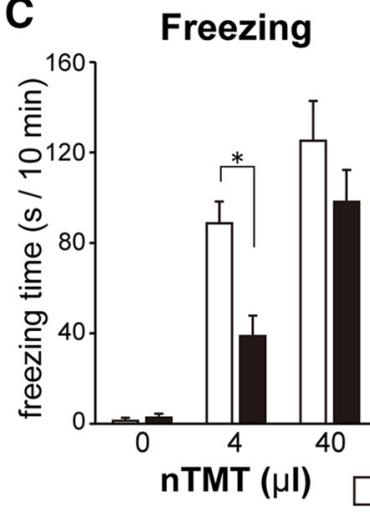

\subsection{Avoidance}

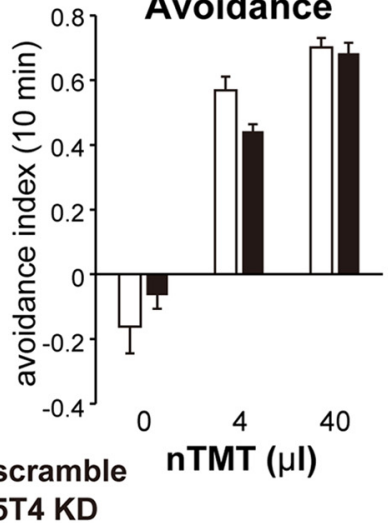

D odor A: eugenol odor B: pentanol OH
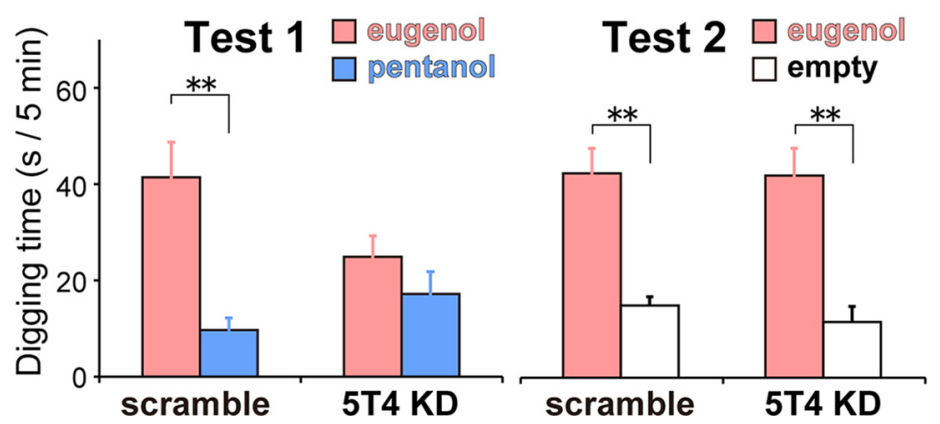

Test $3 \square$ empty pentanol

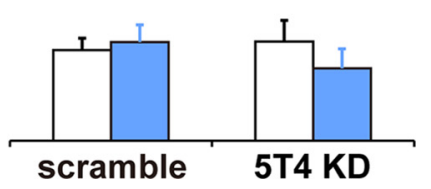

Figure 10. Olfactory behaviors are also impaired in OB-specific $5 T 4 \mathrm{KD}$ mice. A, $5 T 4$ protein production in WT and OB-specific $5 T 4 \mathrm{KD}$ mice. Lentiviral vectors carrying three kinds of H1p-5T4shRNAs were injected into both LVs and OBs of WT mice at P1. OB sections were immunostained with the $5 \mathrm{~T} 4$ antibody (green) at P21. Scale bar, $40 \mu \mathrm{m}$. Right, Signal intensity of $5 T 4$ within the EPL is expressed as the mean \pm SEM ( ${ }^{* *} p=0.009$ vs control OBs; Student's $t$ test; $n=6$ sections from three animals in each line). $B$, Two successive olfactory habituation- dishabituation tests for $5 T 4$ KD mice. Differences in investigation times between the first trial and second trial using eugenol at two different concentrations (Test 1, 6.3 $\mu \mathrm{m} ;$ Test 2, $630 \mu \mathrm{M}$ ) are expressed as the mean \pm SEM ( $p=0.508$, ns; ${ }^{*} p=0.0007$ control vs $5 T 4 \mathrm{KD}$ mice, Welch $t$ test with Holm-Bonferroni correction; $n=12$ control and $n=115 \mathrm{~T} 4 \mathrm{KD}$ animals). C, Olfactory avoidance test for 5 T4 KD mice. Mice were transferred to the test cage and exposed to a filter paper scented with nTMT in 3 different amounts $(0,4$, and $40 \mu \mathrm{l})$. Freezing time and avoidance index during the 10 min test period are expressed as the mean \pm SEM ( ${ }^{*} p=0.002$ control vs $5 T 4 \mathrm{KD}$ mice, Welch $t$ test with Holm-Bonferroni correction; $n=5$ animals in each condition). D, 0 dor discrimination learning test for $5 T 4 \mathrm{KD}$ mice. Digging times during the $5 \mathrm{~min}$ test (Tests 1-3) are represented as bar graphs: eugenol paired with the sugar reward (red) and pentanol unpaired (blue). Digging times are expressed as the mean $\pm \operatorname{SEM}\left({ }^{* *} p=0.00005\right.$, Test 1 , control; $p=0.00005$, Test 2 , control; $p=0.00002$, Test $2,5 T 4 \mathrm{KD}$ between both areas in each test; two-way repeated-measures ANOVA; $n=5$ animal s from each line).

Olfactory behaviors are also impaired in OB-specific 5T4 $K D$ mice

Although global 5T4 KO mice showed impaired olfactory behaviors (Figs. 7, 8, 9), it was unclear whether these phenotypes were due to defects in the dendritic development of 5T4 GCs in the OB alone. Therefore, we performed an OB-specific $5 T 4 \mathrm{KD}$ experiment with three lentiviral vectors expressing different 5T4-shRNAs under the control of the human $\mathrm{H} 1$ promoter (H1p5T4-shRNAs), as described previously (Yoshihara et al., 2012).
Lentiviral vectors carrying three kinds of H1p-5T4-shRNAs were injected into both the LVs and OBs of WT mice at P1, where they infected LV neural stem cells and OB cells such as interneurons and projection neurons. Because 5T4 expression was restricted predominantly to the GAD67-positive interneurons in the $\mathrm{OB}$ (Imamura et al., 2006; Yoshihara et al., 2012), 5T4 KD appeared to be specific to 5T4 GCs in the OB. In fact, IHC of OB sections with the 5T4 antibody indicated that the amount of 5T4 in the dendrites of 5T4 GCs within the EPL was 29\% lower in 5T4 KD 
mice than in control mice, into which three kinds of H1pscramble-shRNAs had been injected (Fig. 10A).

Next, we conducted an olfactory behavior test with 6- to 10week-old OB-specific 5T4 KD mice (P42-P70). In the habituation-dishabituation test, the investigation time of $5 T 4 \mathrm{KD}$ mice was remarkably shorter than that of control mice in Test 1 using eugenol at $6.3 \mu \mathrm{M}(p<0.05 ; n=5$ animals in each condition; Fig. $10 B)$, whereas in Test 2 with $630 \mu \mathrm{M}$ eugenol, the investigation time of $5 T 4 \mathrm{KD}$ mice was similar to that of the control mice (Fig. $10 B)$. Furthermore, in the olfactory avoidance test using the lower amount $(4 \mu \mathrm{l})$ of nTMT, the 5T4 KD mice showed fewer freezing responses than the control mice $(43 \% ; p<0.05$, respectively; $n=5$ animals in each condition; Fig. 10C). These results revealed that odor detection thresholds are higher in OB-specific $5 T 4 \mathrm{KD}$ mice and in global $5 T 4 \mathrm{KO}$ mice (Fig. $7 B, C$ ).

In the odor discrimination learning test with both eugenol and pentanol, 5T4 KD mice did not spend significantly more time digging near the area scented with eugenol (associated with the sugar reward) than near the area scented with pentanol (not associated with the sugar reward) (Fig. 10D). This revealed that $5 T 4$ $\mathrm{KD}$ mice could not discriminate eugenol when both odors were present in Test 1. The OB-specific 5T4 KD showed the same defect as the global 5T4 KO in these olfactory behavior tests (Figs. $7 B, C, 8 B$ ), further suggesting that $5 \mathrm{~T} 4 \mathrm{GCs}$ in the OB are required for both odor detection and odor discrimination behaviors.

\section{Discussion}

\section{Neural circuitry between 5T4 GCs and nonbursting ETCs}

ETCs appear to be glutamatergic projection neurons located either in the GL or at the superficial border of the EPL. In this study, we found that mouse ETCs can be divided into two types, bursting and nonbursting (Fig. 3), as shown previously for the rat $\mathrm{OB}$ (Antal et al., 2006). Recent studies in the rat revealed the characteristic properties of ETCs, especially bursting ETCs, which are defined by their spontaneous periodic burst firings in OB slices and lack of basal dendrites (Hayar et al., 2004a; Antal et al., 2006; Liu and Shipley, 2008). The bursting ETCs modulate the input pattern from olfactory sensory neurons with their intrinsic membrane properties and provide the feedforward excitatory output to MCs (De Saint Jan et al., 2009; Gire et al., 2012). Moreover, bursting ETCs provide monosynaptic glutamatergic input to and receive GABAergic feedback from PGCs and short axon cells (Hayar et al., 2004b; Banerjee et al., 2015). Therefore, the bursting ETC is believed to function as a central unit for the processing of olfactory signals within a glomerulus. Interestingly, we observed optogenetically and electrically evoked $\mathrm{GABA}_{\mathrm{A}}$-PSCs in bursting ETCs (Figs. 4, 5). Our results suggest that GCs may form GABAergic synapses with the cell bodies of bursting ETCs located in the GL near the EPL border. However, we cannot exclude the possibility that optogenetically evoked $\mathrm{GABA}_{\mathrm{A}}$-PSC events in bursting ETCs reflect 5T4-expressing PGCs (5T4 PGCs), only a small fraction of the entire PCGs (Yoshihara et al., 2012).

Compared with the information available for bursting ETCs, we know relatively little about nonbursting ETCs. Although optogenetic stimulation suggested that 5T4 GCs connect to both nonbursting and bursting ETCs (Fig. 4), electrical stimulation showed that $5 T 4 \mathrm{KO}$ mice have fewer inhibitory inputs from GCs to nonbursting ETCs than those from GCs to bursting ETCs (Fig. 5). In addition, electrical stimulation suggested that $\mathrm{GC}$ dendrites connecting to a single, nonbursting ETC are sparsely distributed in the EPL (Fig. 5), as reported previously for the dendrodendritic interactions between MCs and GCs (Fantana et al., 2008; Kim et al., 2011; Kato et al., 2013). The sparse, rather than dense, interactions between GCs and MCs/TCs, including nonbursting ETCs, suggest that the EPL is a lateral inhibitory network in the $\mathrm{OB}$, unlike the nearest-neighbor lateral inhibitory systems in the other modalities such as the retina, which depend on dense interactions (Cook and McReynolds, 1998; Cleland, 2014). Interestingly, optogenetic analysis revealed that a small fraction (9\%) of ChR2-expressing 5T4 GCs induce light-evoked $\mathrm{GABA}_{\mathrm{A}}$-PSCs in 7\% of nonbursting ETCs (Fig. 4). Therefore, we assume that a single nonbursting ETC can usually receive inhibitory input from at least one 5T4 GC. Our results indicate that, among several subtypes of OB GCs, a specific 5T4 GC subtype plays an important role in regulating neural activity in nonbursting ETCs. Furthermore, 5T4 GCs received fewer glutamatergic inputs in 5T4 KO than in WT OBs (Fig. 6). Together, these results suggest that the changes in excitatory and inhibitory transmission involving 5T4 GCs account for the dysfunctional behavior (Figs. 7, 8, 9, 10). However, we cannot exclude the possibility that $5 \mathrm{~T} 4 \mathrm{KO}$ and $\mathrm{KD}$ effects on the behavior are explained by the effects of, not only 5T4 GCs, but also 5T4 PGCs on the neural circuity.

\section{How does the impaired dendritic development in 5T4 GCs influence odor detection thresholds?}

5T4 KO mice showed impaired odor detection in thresholds (Fig. 7). Because we could not obtain any evidence that loss of 5T4 affects the morphologies of MCs/TCs or the intrinsic membrane properties of ETCs (Figs. 2, 3), it is unlikely that the loss of 5T4 reduces the excitability of MCs/TCs. One possible explanation for elevated odor detection thresholds in 5T4 KO mice is that the impaired dendritic development of 5T4 GCs may disturb oscillatory neuronal activities in the $\mathrm{OB}$. The synchronized firing of MCs/TCs induces prominent $\gamma$-range oscillations in the local field potential, which is necessary for effective transmission of the odor signal to the olfactory cortex during awake behaving states (Manabe and Mori, 2013). Dendrodendritic reciprocal synapses between MCs/TCs and GCs participate in the generation of $\gamma$-range oscillations in the OB (Nusser et al., 2001; Lagier et al., 2004). Therefore, the reduced number of inhibitory synaptic connections between 5T4 GCs and nonbursting ETCs in the 5T4 $\mathrm{KO}$ mice may disturb the generation of the synchronized oscillatory firings in ETCs and thus may hinder the transmission of olfactory signals from the $\mathrm{OB}$ to the olfactory cortex, resulting in poor odor detection ability (Fig. 7).

\section{How does impaired dendritic development in 5T4 GCs influence odor discrimination learning?}

OB GCs mediate inhibitory interactions with MCs/TCs, which provide lateral and recurrent inhibitions. When mice sniff an object, the odor information is transformed into a spatial pattern of activated glomeruli in the OB (Mori and Sakano, 2011). The lateral inhibition between GCs and MCs/TCs appears to enhance the contrast between strongly and weakly activated glomeruli and thus sharpens the tuning specificity of individual MCs/TCs to odor molecules (Yokoi et al., 1995; Kato et al., 2012). GCs modulate the activity of MCs/TCs, including nonbursting ETCs, via sparse interactions in the EPL rather than via nearest-neighbor lateral inhibition (Fantana et al., 2008; Kato et al., 2013; Kim et al., 2011; Fig. 5). We reported previously that 5T4 GCs have higher-branching dendrites than non-5T4 GCs (Yoshihara et al., 2012; Fig. 1). Furthermore, nonbursting ETCs broadly elongate their lateral dendrites in the EPL (Igarashi et al., 2012; Fig. 3). Therefore, we speculate that 5T4 GC dendrites may broadly and efficiently regulate the neural activity of nonbursting ETCs in an 
odor-experience-dependent manner. Further, the impaired dendritic development of endogenous 5T4 GCs in $5 T 4 \mathrm{KO}$ mice may result in a failure to reshape neural circuits that execute the unmasking and filtering functions required to discriminate between two odors (Fig. 8). This interpretation is supported by the observation that $5 \mathrm{~T} 4 \mathrm{KO}$ mice cannot discriminate an odor of interest from a background odor in the food-finding test (Fig. 9).

Interestingly, the results for the olfactory behavior task with $5 T 4 \mathrm{KO}$ mice differ from those reported in other studies, in which either inhibition or activation of neural activity in the adult-born $\mathrm{OB}$ interneurons did not have any remarkable effect on either odor detection thresholds or the performance of simple odor discrimination tasks (Abraham et al., 2010; Alonso et al., 2012; Sakamoto et al., 2014). This discrepancy could be due to a difference in subtypes of $\mathrm{OB}$ interneurons genetically manipulated in each study. Because GCs can be divided into several subtypes based on their morphology (Merkle et al., 2014), it is assumed that each GC subtype forms a distinct local circuit in the $\mathrm{OB}$ (Mori et al., 1983; Orona et al., 1983; Shepherd et al., 2004). Several subtypes of GCs are derived from distinct neural stem cells in the SVZ (Fuentealba et al., 2015). Manipulated adultborn GCs are integrated predominantly into deep regions of the OB GC layer and tend to interact with MCs rather than with TCs (Bardy et al., 2010; Sakamoto et al., 2014). In contrast, 5T4 GCs are located in the MC and superficial GC layers and are generated mainly during the embryonic and neonatal stages rather than during the young adult stage (Fig. 1). It is likely that embryonicborn OB interneurons, including 5T4 GCs, play a fundamental role in innate olfactory responses for survival, such as predator avoidance and suckling behaviors (Figs. 7, 8, 9, 10), whereas adult-born $\mathrm{OB}$ interneurons are required for learned olfactory behaviors (Alonso et al., 2012; Sakamoto et al., 2014). A recent study reported that local dendrodendritic circuits within the EPL may segregate into parallel MC and TC (ETC) pathways (Fourcaud-Trocmé et al., 2014). Interestingly, Igarashi et al. (2012) reported that TCs have odor-induced firing responses with shorter latencies at lower concentration thresholds than those of MCs. TCs (ETCs) may be specialized in the fast odor detection and fast behavioral responses that are required for simple discrimination between two distinctly different odors, whereas MCs may be specialized in performing the more difficult task of discriminating between two closely related odors such as enantiomers. This conjecture is consistent with the higher odor detection thresholds of the 5T4 KO mice and their impaired aptitude in odor discrimination learning between two quite different odors, eugenol and pentanol (Figs. 7, 8). Because the loss of $5 T 4$ reduced GC-derived GABAergic inputs onto nonbursting ETCs, but not onto MCs (Fig. 5), it is possible that 5T4 GCs may modulate the ETC pathway preferentially to regulate both odor detection thresholds and simple odor discrimination learning. However, because the activation of ETCs evokes feedforward excitation to MCs (De Saint Jan et al., 2009; Gire et al., 2012), we cannot exclude the possibility that impaired dendritic development of 5T4 GCs in the $5 T 4 \mathrm{KO}$ mice may also affect the MC pathway via nonbursting ETCs. Future studies on MCs and TCs (ETCs) in 5T4 KO mice should help to increase our understanding of their roles in odor-associated behaviors, which are mediated by their interactions with 5T4 GCs in the OB neural circuitry.

\section{References}

Abraham NM, Egger V, Shimshek DR, Renden R, Fukunaga I, Sprengel R, Seeburg PH, Klugmann M, Margrie TW, Schaefer AT, Kuner T (2010)
Synaptic inhibition in the olfactory bulb accelerates odor discrimination in mice. Neuron 65:399-411. CrossRef Medline

Adam Y, Mizrahi A (2010) Circuit formation and maintenance - perspectives from the mammalian olfactory bulb. Curr Opin Neurobiol 20: 134-140. CrossRef Medline

Alonso M, Lepousez G, Sebastien W, Bardy C, Gabellec MM, Torquet N, Lledo PM (2012) Activation of adult-born neurons facilitates learning and memory. Nat Neurosci 15:897-904. CrossRef Medline

Antal M, Eyre M, Finklea B, Nusser Z (2006) External tufted cells in the main olfactory bulb form two distinct subpopulations. Eur J Neurosci 24:1124-1136. CrossRef Medline

Banerjee A, Marbach F, Anselmi F, Koh MS, Davis MB, Garcia da Silva P, Delevich K, Oyibo HK, Gupta P, Li B, Albeanu DF (2015) An interglomerular circuit gates glomerular output and implements gain control in the mouse olfactory bulb. Neuron 87:193-207. CrossRef Medline

Bardy C, Alonso M, Bouthour W, Lledo PM (2010) How, when, and where new inhibitory neurons release neurotransmitters in the adult olfactory bulb. J Neurosci 30:17023-17034. CrossRef Medline

Barrow KM, Ward CM, Rutter J, Ali S, Stern PL (2005) Embryonic expression of murine 5T4 oncofoetal antigen is associated with morphogenetic events at implantation and in developing epithelia. Dev Dyn 233:1535-1545. CrossRef Medline

Bevins RA, Besheer J (2006) Object recognition in rats and mice: a one-trial non-matching-to-sample learning task to study 'recognition memory'. Nat Protoc 1:1306-1311. CrossRef Medline

Breton-Provencher V, Lemasson M, Peralta MR 3rd, Saghatelyan A (2009) Interneurons produced in adulthood are required for the normal functioning of the olfactory bulb network and for the execution of selected olfactory behaviors. J Neurosci 29:15245-15257. CrossRef Medline

Cleland TA (2014) Construction of odor representations by olfactory bulb microcircuits. Prog Brain Res 208:177-203. CrossRef Medline

Cook PB, McReynolds JS (1998) Lateral inhibition in the inner retina is important for spatial tuning of ganglion cells. Nat Neurosci 1:714-719. CrossRef Medline

De Saint Jan D, Hirnet D, Westbrook GL, Charpak S (2009) External tufted cells drive the output of olfactory bulb glomeruli. J Neurosci 29:20432052. CrossRef Medline

Faber DS, Korn H (1991) Applicability of the coefficient of variation method for analyzing synaptic plasticity. Biophys J 60:1288-1294. CrossRef Medline

Fantana AL, Soucy ER, Meister M (2008) Rat olfactory bulb mitral cells receive sparse glomerular inputs. Neuron 59:802-814. CrossRef Medline

Fendt M, Endres T, Lowry CA, Apfelbach R, McGregor IS (2005) TMTinduced autonomic and behavioral changes and the neural basis of its processing. Neurosci Biobehav Rev 29:1145-1156. CrossRef Medline

Fourcaud-Trocmé N, Courtiol E, Buonviso N (2014) Two distinct olfactory bulb sublaminar networks involved in gamma and beta oscillation generation: a CSD study in the anesthetized rat. Front Neural Circuits 8:88. CrossRef Medline

Fuentealba LC, Rompani SB, Parraguez JI, Obernier K, Romero R, Cepko CL, Alvarez-Buylla A (2015) Embryonic origin of postnatal neural stem cells. Cell 161:1644-1655. CrossRef Medline

Gire DH, Franks KM, Zak JD, Tanaka KF, Whitesell JD, Mulligan AA, Hen R, Schoppa NE (2012) Mitral cells in the olfactory bulb are mainly excited through a multistep signaling path. J Neurosci 32:2964-2975. CrossRef Medline

Hayar A, Karnup S, Shipley MT, Ennis M (2004a) Olfactory bulb glomeruli: external tufted cells intrinsically burst at theta frequency and are entrained by patterned olfactory input. J Neurosci 24:1190-1199. CrossRef Medline

Hayar A, Karnup S, Ennis M, Shipley MT (2004b) External tufted cells: a major excitatory element that coordinates glomerular activity. J Neurosci 24:6676-6685. CrossRef Medline

Hole N, Stern PL (1990) Isolation and characterization of 5T4, a tumourassociated antigen. Int J Cancer 45:179-184. CrossRef Medline

Holm S (1979) A simple sequentially rejective multiple test procedure. Scand J Stat 6:65-70.

Igarashi KM, Ieki N, An M, Yamaguchi Y, Nagayama S, Kobayakawa K, Kobayakawa R, Tanifuji M, Sakano H, Chen WR, Mori K (2012) Parallel mitral and tufted cell pathways route distinct odor information to different targets in the olfactory cortex. J Neurosci 32:7970-7985. CrossRef Medline 
Imamura F, Nagao H, Naritsuka H, Murata Y, Taniguchi H, Mori K (2006) A leucine-rich repeat membrane protein, 5T4, is expressed by a subtype of granule cells with dendritic arbors in specific strata of the mouse olfactory bulb. J Comp Neurol 495:754-768. CrossRef Medline

Imayoshi I, Sakamoto M, Ohtsuka T, Takao K, Miyakawa T, Yamaguchi M, Mori K, Ikeda T, Itohara S, Kageyama R (2008) Roles of continuous neurogenesis in the structural and functional integrity of the adult forebrain. Nat Neurosci 11:1153-1161. CrossRef Medline

Ishii T, Omura M, Mombaerts P (2004) Protocols for two- and three-color fluorescent RNA in situ hybridization of the main and accessory olfactory epithelia in mouse. J Neurocytol 33:657-669. CrossRef Medline

Kaneko N, Marín O, Koike M, Hirota Y, Uchiyama Y, Wu JY, Lu Q, TessierLavigne M, Alvarez-Buylla A, Okano H, Rubenstein JL, Sawamoto K (2010) New neurons clear the path of astrocytic processes for their rapid migration in the adult brain. Neuron 67:213-223. CrossRef Medline

Kaneko-Goto T, Sato Y, Katada S, Kinameri E, Yoshihara S, Nishiyori A, Kimura M, Fujita H, Touhara K, Reed RR, Yoshihara Y (2013) Goofy coordinates the acuity of olfactory signaling. J Neurosci 33:12987-12996. CrossRef Medline

Kato HK, Chu MW, Isaacson JS, Komiyama T (2012) Dynamic sensory representations in the olfactory bulb: modulation by wakefulness and experience. Neuron 76:962-975. CrossRef Medline

Kato HK, Gillet SN, Peters AJ, Isaacson JS, Komiyama T (2013) Parvalbumin-expressing interneurons linearly control olfactory bulb output. Neuron 80:1218-1231. CrossRef Medline

Kim DH, Phillips ME, Chang AY, Patel HK, Nguyen KT, Willhite DC (2011) Lateral connectivity in the olfactory bulb is sparse and segregated. Front Neural Circuits 5:5. CrossRef Medline

King KW, Sheppard FC, Westwater C, Stern PL, Myers KA (1999) Organisation of the mouse and human 5T4 oncofoetal leucine-rich glycoprotein genes and expression in foetal and adult murine tissues. Biochim Biophys Acta 1445:257-270. CrossRef Medline

Kobayakawa K, Kobayakawa R, Matsumoto H, Oka Y, Imai T, Ikawa M, Okabe M, Ikeda T, Itohara S, Kikusui T, Mori K, Sakano H (2007) Innate versus learned odour processing in the mouse olfactory bulb. Nature 450:503-508. CrossRef Medline

Lagier S, Carleton A, Lledo PM (2004) Interplay between local GABAergic interneurons and relay neurons generates gamma oscillations in the rat olfactory bulb. J Neurosci 24:4382-4392. CrossRef Medline

Le Pichon CE, Valley MT, Polymenidou M, Chesler AT, Sagdullaev BT, Aguzzi A, Firestein S (2009) Olfactory behavior and physiology are disrupted in prion protein knockout mice. Nat Neurosci 12:60-69. CrossRef Medline

Lepousez G, Valley MT, Lledo PM (2013) The impact of adult neurogenesis on olfactory bulb circuits and computations. Annu Rev Physiol 75: 339-363. CrossRef Medline

Lin CW, Sim S, Ainsworth A, Okada M, Kelsch W, Lois C (2010) Genetically increased cell-intrinsic excitability enhances neuronal integration into adult brain circuits. Neuron 65:32-39. CrossRef Medline

Liu S, Shipley MT (2008) Multiple conductances cooperatively regulate spontaneous bursting in mouse olfactory bulb external tufted cells. J Neurosci 28:1625-1639. CrossRef Medline

Livneh Y, Feinstein N, Klein M, Mizrahi A (2009) Sensory input enhances synaptogenesis of adult-born neurons. J Neurosci 29:86-97. CrossRef Medline

Lledo PM, Merkle FT, Alvarez-Buylla A (2008) Origin and function of olfactory bulb interneuron diversity. Trends Neurosci 31:392-400. CrossRef Medline

Macrides F, Schneider SP (1982) Laminar organization of mitral and tufted cells in the main olfactory bulb of the adult hamster. J Comp Neurol 208:419-430. CrossRef Medline

Madisen L, Mao T, Koch H, Zhuo JM, Berenyi A, Fujisawa S, Hsu YW, Garcia AJ 3rd, Gu X, Zanella S, Kidney J, Gu H, Mao Y, Hooks BM, Boyden ES, Buzsáki G, Ramirez JM, Jones AR, Svoboda K, Han X, Turner EE, Zeng H (2012) A toolbox of Cre-dependent optogenetic transgenic mice for light-induced activation and silencing. Nat Neurosci 15:793-802. CrossRef Medline

Manabe H, Mori K (2013) Sniff rhythm-paced fast and slow gammaoscillations in the olfactory bulb: relation to tufted and mitral cells and behavioral states. J Neurophysiol 110:1593-1599. CrossRef Medline

Merkle FT, Fuentealba LC, Sanders TA, Magno L, Kessaris N, Alvarez-Buylla A (2014) Adult neural stem cells in distinct microdomains generate pre- viously unknown interneuron types. Nat Neurosci 17:207-214. CrossRef Medline

Mori K, Sakano H (2011) How is the olfactory map formed and interpreted in the mammalian brain? Annu Rev Neurosci 34:467-499. CrossRef Medline

Mori K, Kishi K, Ojima H (1983) Distribution of dendrites of mitral, displaced mitral, tufted, and granule cells in the rabbit olfactory bulb. J Comp Neurol 219:339-355. CrossRef Medline

Neher E (1992) Correction for liquid junction potentials in patch clamp experiments. Methods Enzymol 207:123-131. CrossRef Medline

Nithianantharajah J, Hannan AJ (2006) Enriched environments, experience-dependent plasticity and disorders of the nervous system. Nat Rev Neurosci 7:697-709. CrossRef Medline

Nunes D, Kuner T (2015) Disinhibition of olfactory bulb granule cells accelerates odour discrimination in mice. Nat Commun 6:8950. CrossRef Medline

Nusser Z, Kay LM, Laurent G, Homanics GE, Mody I (2001) Disruption of GABA(A) receptors on GABAergic interneurons leads to increased oscillatory power in the olfactory bulb network. J Neurophysiol 86:2823-2833. Medline

Orona E, Scott JW, Rainer EC (1983) Different granule cell populations innervate superficial and deep regions of the external plexiform layer in rat olfactory bulb. J Comp Neurol 217:227-237. CrossRef Medline

Orona E, Rainer EC, Scott JW (1984) Dendritic and axonal organization of mitral and tufted cells in the rat olfactory bulb. J Comp Neurol 226: 346-356. CrossRef Medline

Ranjan A, Mallick BN (2010) A modified method for consistent and reliable Golgi-Cox staining in significantly reduced time. Front Neurol 1:157. CrossRef Medline

Renier N, Wu Z, Simon DJ, Yang J, Ariel P, Tessier-Lavigne M (2014) iDISCO: a simple, rapid method to immunolabel large tissue samples for volume imaging. Cell 159:896-910. CrossRef Medline

Rochefort C, Gheusi G, Vincent JD, Lledo PM (2002) Enriched odor exposure increases the number of newborn neurons in the adult olfactory bulb and improves odor memory. J Neurosci 22:2679-2689. Medline

Saghatelyan A, Roux P, Migliore M, Rochefort C, Desmaisons D, Charneau P, Shepherd GM, Lledo PM (2005) Activity-dependent adjustments of the inhibitory network in the olfactory bulb following early postnatal deprivation. Neuron 46:103-116. CrossRef Medline

Sakamoto M, Imayoshi I, Ohtsuka T, Yamaguchi M, Mori K, Kageyama R (2011) Continuous neurogenesis in the adult forebrain is required for innate olfactory responses. Proc Natl Acad Sci U S A 108:8479-8484. CrossRef Medline

Sakamoto M, Ieki N, Miyoshi G, Mochimaru D, Miyachi H, Imura T, Yamaguchi M, Fishell G, Mori K, Kageyama R, Imayoshi I (2014) Continuous postnatal neurogenesis contributes to formation of the olfactory bulb neural circuits and flexible olfactory associative learning. J Neurosci 34: 5788-5799. CrossRef Medline

Sanes JR, Lichtman JW (2001) Induction, assembly, maturation and maintenance of a postsynaptic apparatus. Nat Rev Neurosci 2:791-805. Medline

Serizawa S, Miyamichi K, Takeuchi H, Yamagishi Y, Suzuki M, Sakano H (2006) A neuronal identity code for the odorant receptor-specific and activity-dependent axon sorting. Cell 127:1057-1069. CrossRef Medline

Shepherd GM, Chen WR, Greer CA (2004) Olfactory bulb. In: The synaptic organization of the brain (Shepherd GM, ed), pp 165-216. Oxford: OUP.

Southall PJ, Boxer GM, Bagshawe KD, Hole N, Bromley M, Stern PL (1990) Immunohistological distribution of 5T4 antigen in normal and malignant tissues. Br J Cancer 61:89-95. CrossRef Medline

Southgate TD, McGinn OJ, Castro FV, Rutkowski AJ, Al-Muftah M, Marinov G, Smethurst GJ, Shaw D, Ward CM, Miller CJ, Stern PL (2010) CXCR4 mediated chemotaxis is regulated by $5 \mathrm{~T} 4$ oncofetal glycoprotein in mouse embryonic cells. PLoS One 5:e9982. CrossRef Medline

Torashima T, Yamada N, Itoh M, Yamamoto A, Hirai H (2006) Exposure of lentiviral vectors to subneutral $\mathrm{pH}$ shifts the tropism from Purkinje cell to Bergmann glia. Eur J Neurosci 24:371-380. CrossRef Medline

Tsuboi A, Yoshihara S, Yamazaki N, Kasai H, Asai-Tsuboi H, Komatsu M, Serizawa S, Ishii T, Matsuda Y, Nagawa F, Sakano H (1999) Olfactory neurons expressing closely linked and homologous odorant receptor genes tend to project their axons to neighboring glomeruli on the olfactory bulb. J Neurosci 19:8409-8418. Medline

Vernet-Maury E, Polak EH, Demael A (1984) Structure-activity relation- 
ship of stress-inducing odorants in the rat. J Chem Ecol 10:1007-1018. CrossRef Medline

Whitman MC, Greer CA (2009) Adult neurogenesis and the olfactory system. Prog Neurobiol 89:162-175. CrossRef Medline

Yamaguchi M, Mori K (2005) Critical period for sensory experiencedependent survival of newly generated granule cells in the adult mouse olfactory bulb. Proc Natl Acad Sci U S A 102:9697-9702. CrossRef Medline

Yokoi M, Mori K, Nakanishi S (1995) Refinement of odor molecule tuning by dendrodendritic synaptic inhibition in the olfactory bulb. Proc Natl Acad Sci U S A 92:3371-3375. CrossRef Medline

Yoshihara S, Omichi K, Yanazawa M, Kitamura K, Yoshihara Y (2005) Arx homeobox gene is essential for development of mouse olfactory system. Development 132:751-762. CrossRef Medline

Yoshihara S, Takahashi H, Nishimura N, Naritsuka H, Shirao T, Hirai H, Yoshihara Y, Mori K, Stern PL, Tsuboi A (2012) 5T4 glycoprotein regulates the sensory input-dependent development of a specific subtype of newborn interneurons in the mouse olfactory bulb. J Neurosci 32:22172226. CrossRef Medline

Yoshihara S, Takahashi H, Nishimura N, Kinoshita M, Asahina R, Kitsuki M, Tatsumi K, Furukawa-Hibi Y, Hirai H, Nagai T, Yamada K, Tsuboi A (2014) Npas4 regulates Mdm2 and thus Dcx in experience-dependent dendritic spine development of newborn olfactory bulb interneurons. Cell Rep 8:843-857. CrossRef Medline 